\title{
Systematic literature review paper: the regional innovation system-university-science park nexus
}

\author{
T. Theeranattapong ${ }^{1} \cdot$ D. Pickernell ${ }^{1}$ (D) C. Simms ${ }^{1}$ (D)
}

Accepted: 8 December 2020 / Published online: 2 January 2021

(c) Crown 2021

\begin{abstract}
Recent work on Region Innovation Systems (RIS) has emphasised the importance of universities. Until recently, however, related insights into the dynamics of this relationship in respect of the specific role of the science park have been limited. This paper presents a systematic review identifying the key roles of each actor in relation to innovation. We link the dynamic roles performed by the university between science parks and the RIS. Our results enable us to identify how the key activities performed by the university change during its interrelations within the RIS and with the science park. Our analysis of the literature distinguishes between three sets of relationships through which the university plays differing roles: RIS-university, RIS-university-science park, and university-science park. Respectively, the University's relationships between these different RIS actors focuses on: resource sharing, brokerage, and commercialisation-exploitation. Secondly, we find that within each of these relationship types the university can perform three types of roles: on knowledge co-creation, acting as conduit, and inter-organisational relationship building. Distinguishing between these differing relationships and roles enables us to identify a total of nine dynamic roles performed by the University, which include: provision of information, channels of communication, infrastructure, regional networking, building research collaboration, acting as knowledge intermediaries, economic development, technological change and commercialisation processes, and start up creation and commercialisation. The review identifies several gaps in the literature in need of further research, and suggests that university relationships with RIS, interlinked with those between the university and science park itself, are important factors affecting science park innovation performance.
\end{abstract}

Keywords Science park - University $\cdot$ Regional innovation system $\cdot$ Technology transfer

C. Simms

chris.simms@port.ac.uk

1 Strategy, Enterprise and Innovation Subject Group, Faculty of Business and Law, University of Portsmouth, Richmond Building, Portland Street, Portsmouth PO13DE, UK 


\section{Introduction}

Universities' traditional roles, of teaching and research, are increasingly being supplemented by government policies aimed at increasing the "entrepreneurial" activities as a way to help develop the economy, for example through student start-ups (Wright et al. 2017). Whilst it is not new, the "entrepreneurial university" concept adopted by a growing number of universities has supplemented the two traditional roles of universities with the need to help develop regional economies (e.g. Etzkowitz and Leydesdorff 1999; Gunasekara 2006; Malairaja and Zawdie 2008). Consequently universities, through the concept of the triple helix (Etzkowitz and Leydesdorff 2000), are increasingly participating in entrepreneurial activities (see for example, Etzkowitz et al. 2000).

Policy makers and governments are increasingly looking to Universities to contribute to the regional innovation system (RIS) and/or entrepreneurial ecosystem (Feldman et al. 2019), as part of building the knowledge based economy and fostering regional competitiveness. This role of the university in regional economic and social development has heavily influenced policy over the past 20 years (Acs et al. 2009; Etzkowitz and Leydesdorff 1996, 1999), further altering the role of universities. Science parks (SPs) act as an important tool in regional development policy, and can be considered as property-based policy interventions to support commercialization of research results from universities (Appold 2004; Vedovello 2002). This paper, therefore attempts to link the literatures concerning RIS and SPs, via the role of the entrepreneurial university, to provide understanding of how SPs are conceptualised and how these literatures link findings on universities and SP's to the RIS.

In both RIS and science park literatures universities play a critical role. They form a key and integral component in the RIS and have important linkages with science parks. There has, however, been no systematic integrated investigation into how the roles performed by the university change depending on the nature of the interaction and the actor involved. Moreover, only a limited number of studies focused on science parks incorporate the RIS, with even fewer focused on the university as a key stakeholder within this. This gap therefore requires us first to integrate findings from these two literatures and identify what they have found and focused on thus far. Then we focus specifically on two basic research questions: First, what are the key roles and foci of the university in its relationships with the science park, within the RIS? Second, how do these key roles and foci change through interrelations between university, science park and the surrounding RIS environment?

In both RIS and science park literatures universities play a critical role. They form a key and integral component in the RIS and have important linkages with science parks. There has, however, been no systematic integrated investigation into how the roles performed by the university change depending on the nature of the interaction and the actor involved. Moreover, only a limited number of studies focused on science parks incorporate the RIS, with even fewer focused on the university as a key stakeholder within this. This gap therefore requires us first to integrate findings from these two literatures and identify what they have found and focused on thus far. Then we focus specifically on two basic research questions: First, what are the key roles and foci of the university in its relationships with the science park, within the RIS? Second, how do these key roles and foci change through interrelations between university, science park and the surrounding RIS environment?

In order to answer these questions this paper follows a systematic literature review approach constructed from literatures on "science parks" and "RIS incorporating science parks" with the intention of linking both literatures together. This approach provides 
a framework of protocols through which the relevant literature is identified, findings reported, and contribution of the study and research gaps identified (Macpherson and Holt 2007; Tranfield et al. 2003).

The findings of our review provide three key contributions to the literature. First, we clarify the three types of relationships between the university and the key stakeholders: knowledge co-creation, acting as conduit, and inter-organisational relationship building. Second we identify three specific roles performed by the University: resource sharing, brokerage, and commercialisation-exploitation. Third, we identify how the University's roles change during its interactions between RIS-university, RIS-university-science park, and university-science park, identifying nine specific sets of activities the University performs, which depend on the focus-role interdependency.

The next section begins with a brief discussion of the ex ante literature, focusing on the definition of RIS actors and dynamics of the local innovation ecosystems. This is followed by a description of the research methodology. A review protocol is developed, publications are selected and grouped and classified, prior to reporting the results of the subsequent analysis. Finally, we identify gaps for future research.

\section{Ex ante literature review}

The RIS approach incorporates the development of the "entrepreneurial university" with knowledge spillovers. The interrelationships between the triple helix actors to encourage learning processes in the region also form key aspects of the RIS, which has resulted in universities expanding and updating their research agendas to better meet industrial needs and enhance links with industry (Vedovello 2002). For example, academic researchers are able to commercialise their research results and exchange knowledge with firms located on the science park. In so doing, science parks offer a crucial resource network for new technology-based firms (NTBFs) (Westhead 1997). This then both fosters and supplements the role of the science park as an interactive mechanism for systemic university-industry cooperation (Asheim and Coenen 2006; Vedovello 2002).

The RIS represents an interconnected context and resource, defined in terms of both actors and dynamics within the local innovation ecosystem. In terms of actors, the importance of innovative local agencies (Asheim and Isaksen 2002), regional and local government governance actors and institutions (including universities), also science parks (Zhang 2015), other key infrastructure providers (Gerstlberger 2004; Takeda et al. 2008), and the international connections (Lew et al. 2018) have been identified.

In terms of dynamics, Zhang (2015) then highlights national and local policies in human resources and land development, whilst Asheim and Coenen (2005) identify that "regional culture" is relevant to knowledge production and uptake (Rip 2002). Cooke and Morgan 1998). To design a sustainable RIS researchers have indicated that resourcing the development of relevant infrastructure is one of the criteria necessary for success, the infrastructure itself forms an essential determinant for firm location choice (Gerstlberger 2004; Takeda et al. 2008). Cooke and Morgan (1998) also identify that robust RIS also have levels of institutional thickness, with different actors playing different roles at different levels.

In the case of universities, Fuller et al. (2019), Pickernell et al. (2019) and Ishizaka et al. (2020) identify, previous dichotomous definitions of universities into being research or teaching focused, can now be seen to be too simplistic. Universities instead exist along a spectrum between these two extremes, offering different combinations of supporting 
relevant research and training activities within RIS. Whilst as will be seen, there is no consensus on what constitutes a science park, broadly they can be seen as characterised by links with academic institutions (usually research focused), supporting start-up/incubation of technology-based firms, fostering transfer of technology and business knowledge, property-based, and sustainable (Durão et al. 2005). Science parks also help (usually more research-focused) universities build and improve their reputation (Helmers 2019; Link and Scott 2017) within the RIS.

\section{Methodology}

In order to be systematic, transparent and replicable, our review involved two processes. This follows the approach of Macpherson and Holt (2007), who themselves followed refined protocols outlined by Tranfield et al. (2003) and Pittaway et al. (2004). First, we define the review protocols and map the literature by: (1) accessing, (2) retrieving and (3) judging the quality and relevance of the literature in relation to the research topic, according to explicit inclusion and exclusion criteria. As part of this we classify the quality of papers, following Turner et al. (2013) approach of selecting papers categorised by journal rating (based on the Chartered Association of Business School's (CABS) Academic Journal Guide 2018). This produced the following review protocols and processes, summarized in the table below, and then discussed in more detail (Table 1).

\subsection{Review protocols}

The papers included in this study were identified from the electronic databases Business Source Complete, Web of Science, and Scopus restricted to English language academic papers in the categories of "technological innovations, research parks, technology, and business incubators" (Business Source Complete), "business and management" (Web of Science), and "business, management and accounting" (Scopus).

Three inclusion criteria were used within our systematic review process: (1) Papers that reviewed secondary data analysis if the purpose of the review was to identify future research or policy agendas because they offer the working assumptions to be used in this study, or primary quantitative or qualitative empirical studies. (2) Articles had to be published after 1990. This time period is selected due to the concept of RIS most consistently appearing and being developed during the 1990s, the literature on science parks also most strongly observed during this period, and also the need to focus on policy developments in the context of these more recent developments. (3) Following Savino et al. (2017) only academic journal articles were included. It must be recognised that the approach taken has

Table 1 Summary of systematic review articles retrieval and analysis

\begin{tabular}{llll}
\hline Stage & $\begin{array}{l}\text { Number of docu- } \\
\text { ments }\end{array}$ & Excluded documents & $\begin{array}{l}\text { Number of } \\
\text { relevant docu- } \\
\text { ment }\end{array}$ \\
\hline $\begin{array}{l}\text { 1: Primary Search String Analysis using } \\
\text { Inclusion Criteria }\end{array}$ & 1735 & 646 (Duplicates) & 1089 \\
\begin{tabular}{l} 
2: Application of Exclusion Criteria \\
\hline
\end{tabular} & 1089 & 938 & 151 \\
\hline
\end{tabular}


deliberately excluded non-journal outputs from the review, which will potentially exclude relevant and important contributions from books, such as Link and Scott (2015) and Wright et al. (2019). This follows the approach of Keupp et al. (2012), in which book reviews, book chapters, conference proceedings and working papers were excluded.

An initial list of keywords based on ex ante analysis of the literature yielded 3 keywords. We then conducted Boolean searches on combinations of the keywords (and their variants, to acknowledge the different terminologies used around the world.) identified. For example, these searches included 'Science park', 'Research park', 'Technopole', 'HighTech park', 'Technology park', 'Regional Innovation System' and Science park'. The total number of potentially relevant articles retrieved using search strings alone was 1735 .

Once duplicate articles were excluded, 1089 papers remained. To then identify the papers directly related to the topic and classify these papers, the papers were evaluated systematically, beginning with the journal quality, then examining the content of abstract and introduction, literature review, and conclusion in order to exclude irrelevant articles (using the exclusion criteria in Table 2).

\subsection{Mapping the field}

Utilising the described process, 151 papers were identified as directly related to the topic. Table 3 categorises these articles by journal in Table 3, using ratings from the CABS Guide 2018. 90 papers were published in journals rated as CABS4 or CABS3 $(59.60 \%)$, while 61 papers were rated as CABS2 (40.40\%), shown in Table 3 according to the numbers of selected papers published in each journal. Technovation and the

Table 2 Stage 2 exclusion criteria

\begin{tabular}{ll}
\hline & Exclusion criteria \\
\hline The quality of the articles & Journals rated as $1^{*}$ or that did not appear in the Chartered Association of \\
& Business Schools (CABS) Guide 2018 \\
Literature on Science parks & The studies were not relevant to science park OR \\
The studies were tangentially related to science park, but primarily focused on \\
Urban planning and city design \\
Intellectual property management and/or patents \\
Modelling growth and productivity \\
Industrial cluster policy \\
The effects of government fiscal incentives \\
Venture capitalists (VCs) \\
The growth of information technology (IT) industry \\
The impact of returnee entrepreneurs and their knowledge spillover \\
Recombinant distance \\
Proof of Concept (PoC) process \\
The paper did not describe the concept of RIS and did not refer to science \\
parks or other terms for science park. \\
The studies were only tangentially related to RIS, referring to science parks, \\
but primarily focused on \\
The relationships between regional innovation initiatives (RII), knowledge- \\
intensive business services (KIBSs) and value chain information sources on \\
absorptive capacity (AC) and innovation performance \\
The Open Regional Innovation System (ORIS model) \\
Product innovations in manufacturing industries \\
Literature on RIS
\end{tabular}


Table 3 Journals and a number of selected papers

\begin{tabular}{ll}
\hline Qty. of papers & Journals \\
\hline 33 & Technovation (CABS3) \\
30 & Journal of Technology Transfer (CABS2) \\
13 & European Planning Studies (CABS2) \\
10 & Research Policy (CABS4) \\
7 & R\&D Management (CABS3) \\
7 & International Journal of Technology Management (CABS2) \\
7 & Technology Analysis \& Strategic Management (CABS2) \\
5 & Regional Studies (CABS3) \\
5 & Small Business Economics (CABS3) \\
5 & Technological Forecasting \& Social Change (CABS3) \\
3 & Journal of Business Venturing (CABS4) \\
3 & Entrepreneurship \& Regional Development (CABS3) \\
3 & International Journal of Industrial Organization (CABS3) \\
3 & Urban Studies (CABS3) \\
2 & Industrial and Corporate Change (CABS3) \\
2 & Journal of Small Business Management (CABS3) \\
1 & Environment and Planning A (CABS4) \\
1 & Environment and Planning D (CABS4) \\
1 & Journal of Economic Geography (CABS4) \\
1 & Journal of Management Studies (CABS4) \\
1 & International Business Review (CABS3) \\
1 & Industrial Marketing Management (CABS3) \\
1 & Journal of Business Research (CABS3) \\
1 & New Technology Work and Employment (CABS3) \\
1 & Omega: The International Journal of Management Science (CABS3) \\
1 & Asia Pacific Business Review (CABS2) \\
1 & Journal of Business \& Industrial Marketing (CABS2) \\
1 & Journal of Productivity Analysis (CABS2) \\
1 & \\
\hline $\mathbf{1 5 1}$ & \\
\hline & \\
\hline &
\end{tabular}

Journal of Technology Transfer, given their focus, demonstrated the strongest discourse around the relevant issues in terms of papers. The average number of papers from 1990 to 2019 was approximately 5 papers per year, with concentrations for science parks around the years 2003, 2005, 2006, 2008 and RIS-science parks around year 2002 and 2005.

Focusing on the overlaps in broad topic area covered by the papers, 119 articles originate from the science park literature, seventy-one of these also indicating the roles and interactions of the university and science park. The remaining thirty-two articles had a RIS literature emphasis, whilst incorporating science parks within their analysis (i.e. RIS with a science park emphasis). These articles can be divided into: (1) eighteen papers which referred to the science park and asserted the roles and interactions of university and RIS, (2) eight papers referring to the science park but focused mainly on RIS and without the university, (3) two paper conducting research on the science park and relevant to 
RIS concepts without mentioning the university, and (4) four papers conducting research focused on the science park and including both RIS concepts and the role of the university.

With respect to the study locations, the literature on science park without a RIS-science park emphasis is shown in Table 4 . The results identify a concentration on single country studies, particularly in the Taiwan, UK, Sweden, China and Spain. Conversely, the literature on RIS-science park emphasis (Table 5) is relatively more focused on multi-country studies, with a strong focus on more developed economies.

Finally, in terms of the analytical focus of the papers, (shown in Table 6), secondary review papers and mixed method papers each have $10.60 \%$ of the total. Overall, there is a

Table 4 The study locations in the literature on science park without reference to RIS-science park emphasis

\begin{tabular}{lll}
\hline Country & No. of papers & $\%$ \\
\hline Taiwan & 13 & 10.924 \\
UK & 13 & 10.924 \\
Sweden & 11 & 9.244 \\
China & 10 & 8.403 \\
Spain & 10 & 8.403 \\
2 Countries & 8 & 6.723 \\
Italy & 7 & 5.882 \\
N/A & 7 & 5.882 \\
USA & 6 & 5.042 \\
Japan & 3 & 2.521 \\
European countries & 2 & 1.681 \\
France & 2 & 1.681 \\
Germany & 2 & 1.681 \\
Greece & 2 & 1.681 \\
Malaysia & 2 & 1.681 \\
Portugal & 2 & 1.681 \\
Singapore & 2 & 1.681 \\
South Korea & 2 & 1.681 \\
Australia & 1 & 0.840 \\
Brazil & 119 papers & 0.840 \\
Canada & & 0.840 \\
Finland & 1 & 0.840 \\
Hong Kong & 1 & 0.840 \\
Hungary & 1 & 0.840 \\
India & 1 & 0.840 \\
Israel & 1 & 0.840 \\
Kazakhstan & 1 & 0.840 \\
Russia & 1 & 0.840 \\
Saudi Arabia & 1 & 0.840 \\
South Africa & 1 & 0.840 \\
Thailand & 1 & 0.840 \\
Turkey & 0.840 \\
More than three countries & 1 & \\
Total & 1 & \\
\hline & 1 & \\
\hline
\end{tabular}


Table 5 The study locations in the literature on RIS-science park emphasis

\begin{tabular}{llc}
\hline Country & No. of papers & $\%$ \\
\hline 2 Countries & 6 & 18.75 \\
Italy & 3 & 9.375 \\
3 Countries & 2 & 6.250 \\
Canada & 2 & 6.250 \\
China & 2 & 6.250 \\
N/A & 2 & 6.250 \\
Norway & 2 & 6.250 \\
Spain & 2 & 6.250 \\
Sweden & 2 & 6.250 \\
Australia & 1 & 3.125 \\
Austria & 1 & 3.125 \\
Germany & 1 & 3.125 \\
Greece & 1 & 3.125 \\
Japan & 1 & 3.125 \\
More than three countries & 1 & 3.125 \\
South Korea & 1 & 3.125 \\
The Netherlands & 1 & 3.125 \\
Turkey & 1 & 3.125 \\
Overall & 32 papers \\
\hline
\end{tabular}

relative concentration on qualitative over quantitative studies, particularly for RIS with a science park emphasis, whilst most of the mixed methods papers are focused on Science park.

\subsection{Reporting the findings}

Following Savino et al. (2017) the analysis of the literature is divided into two sections, informed by the Research Questions. We follow processes similar to Macpherson and Holt (2007), by first providing a broad descriptive review of the literature (Tranfield et al. 2003), according to the broad RIS-University-Science Park framework on which the data had been initially collected, to identify context. Following this, continuous inductive and iterative coding and sensemaking processes (Williams 2002), compared the literature to generate summarizing themes through which the different roles of the university in RIS actors-university-science park nexus could be identified.

\section{The broad RIS-university-science park context}

\subsection{Defining the science park}

The concept of science parks can be traced back to the 1950s when the Stanford Science Park was founded by Stanford University in California. Science parks boomed throughout Europe during the 1980s and 1990s (Bakouros et al. 2002; Storey and Tether 1998), and in Asian countries in the mid-1980s (Phan et al. 2005). Simultaneously, a number of other 


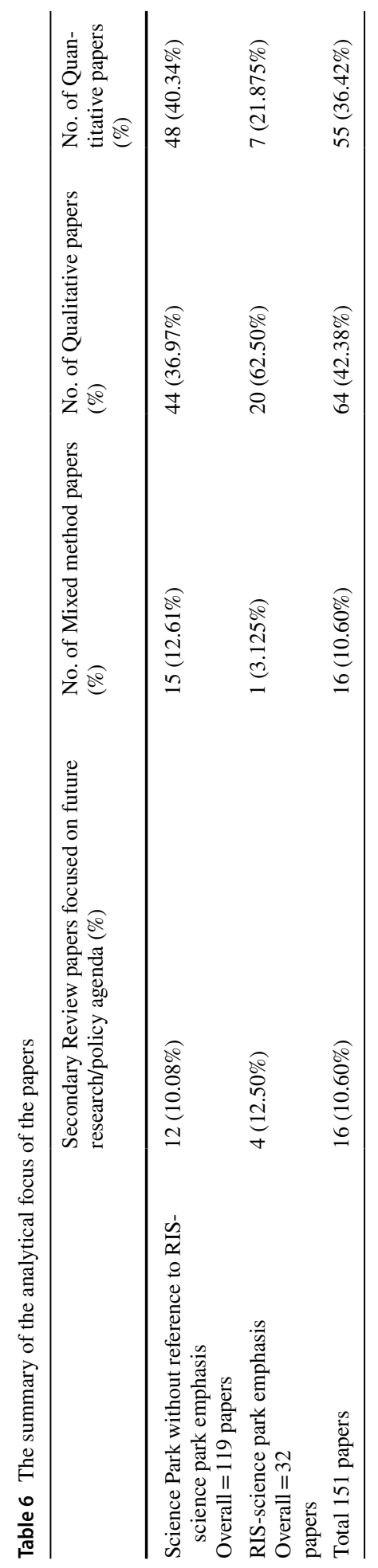


types of property-based developments with similar roles to science parks exist, particularly technology parks, technopoles, innovation parks, and research parks (Sofouli and Vonortas 2007). According to Link and Scott (2003a, b) each can distinguished as follows: (1) research parks are characterized by tenants that are mostly engaged in basic and applied research, (2) science parks (including technology parks) are characterized by tenants that are more heavily engaged in applied research and development, (3) technology or innovation parks in particular often house new start-up companies and incubation facilities. Commercial or industrial parks can also be distinguished from science parks on the basis of their tenants who apply value-adding activities to existing R\&D-based products or production-orientated activities, as opposed to conducting R\&D activities (Cheng et al. 2014; Huang et al. 2012; Link and Scott 2003b). Also, whilst Technopoles and initiatives like the multimedia super corridor (MSC) often share similar goals to science parks (Boucke et al. 1994; Chordà 1996; Ramasamy et al. 2004), they differ in often being created by government and having a much larger physical scale (Chordà 1996; Ramasamy et al. 2004).

Given the above discussion, however, there is no uniformly accepted definition for the science park (Cheng et al. 2014; Fukugawa 2006; Hansson et al. 2005; Lindelöf and Löfsten 2006; A. Link and Link 2003; A. N. Link and Scott 2003b; Löfsten and Lindelöf 2001, 2002, 2003). Phan et al. (2005) also demonstrates that no general theory for the science park exists due to the origins and consequences of the parks being varied depending on their economic geography, political and social context, as well as, economic systems. In brief, however, a science park is typically characterised by: (1) having links with academic institutions (2) supporting the start-up and incubation of technology-based firms (3) fostering the transfer of technology and business knowledge, (4) property-based initiatives, and (5) their sustainable nature (Durão et al. 2005). Universities then obtain income from technology transfer as well as receiving opportunities for their personnel and students from interacting at applied levels with technology-based organisations, science parks also helping universities build and improve reputation (Helmers 2019; Link and Scott 2017).

Whilst universities are often instrumental in founding science parks, this activity is more concentrated in some countries and universities than others. In the UK, the Cambridge, Heriot-Watt, and Surrey Science Parks were each set up by universities (Westhead and Batstone 1998) whilst in Sweden, universities have worked alongside local authorities and development agencies to encourage the formation of heterogeneous groups of parks (Lindelöf and Löfsten 2006). By contrast, the Kista science park evolved from a cluster centred on Ericsson into the Kista Science City and did not need a university as a precursor to its establishment (Cabral 1998). Whilst in Japan the "centre facility" approach involves a public-private organization takes on the role of the university to offer facilities and services to entrepreneurs (Bass 1998).

$\mathrm{Ng}$ et al. (2019) also indicate that science park ownership has diversified to include combinations of public and/or private sector actors, which can also affect the focus of their activities. The privately owned Kilometro Rosso Science Park in Italy, for example, specifically aims to promote networking amongst relevant partnerships as well as enhancing interactions between on-park and off-park firms (Corsaro and Cantù 2015), Layson et al. (2008) also identified that privately owned science parks often seek to limit the number of firms in the park, even where there is nominally free entry. Conversely, university owned science parks more specifically focus on knowledge spillovers (Alshumaimri et al. (2017) offering the entrepreneur access to the intellectual resources of academic staff and advice to establish a new venture (Wright et al. 2008), but also provide less access to commercially oriented expertise and contacts than non university-affiliated parks. According to Albahari et al. (2017), higher university involvement also positively affects tenant firm patent 
applications but negatively affects their innovation-related sales. Therefore, a universityowned science park is likely to be a strategic choice for a firm with both benefits and costs.

\subsection{The performance of science parks}

In terms of performance, science parks clearly aim to generate the growth of new technology-based firms (NTBFs), on-park firms are expected to "perform better" or benefit from greater "added value" than equivalent off-park firms (Löfsten and Lindelöf 2002; Radosevic and Myrzakhmet 2009). However, Markman et al. (2008) indicate that there is a problem in terms of defining science park effectiveness, particularly with respect to measures of on-park firm survival, wealth creation, and employment growth. To explore effectiveness, researchers have therefore compared on-park with off-park firms in terms of: innovative performance (Chan et al. 2010; Lindelöf and Löfsten 2003; Löfsten and Lindelöf 2001; Radosevic and Myrzakhmet 2009), facilities management (FM) (Dettwiler et al. 2006), R\&D productivity of firms (Siegel et al. 2003a; C. H. Yang et al. 2009), the performance of firms (Löfsten and Lindelöf 2003), product development (Lindelöf and Löfsten 2004), perceived benefits of being in a science park (Westhead and Batstone 1998), survival and growth rates (Ferguson and Olofsson 2004), improvement in economic performance and innovative capacity (Liberati et al. 2016), contribution to NTBFs (Fukugawa 2006), links with local HEIs (Storey and Tether 1998), R\&D "inputs" and "outputs" (Westhead 1997), innovative output (Squicciarini 2008), university-industry collaboration (Malairaja and Zawdie 2008), performance of NTBFs (Siegel et al. 2003b), absorptive capacity (Ubeda et al. 2019), local knowledge exchange and innovation promotion (Díez-Vial and Fernández-Olmos 2015), economic recession performance effects (Díez-Vial and FernándezOlmos 2017), growth and innovativeness (Lamperti et al. 2017), establishment and growth of new technology-based firms (NTBFs) (Colombo and Delmastro 2002), cooperation for innovation (Vásquez-Urriago et al. 2016) and innovation performance of NTBFs (RamírezAlesón and Fernández-Olmos 2018).

Given this plethora of potential performance measures there are many identified determinants of science park performance. For example, a strong management team is recognized as a characteristic of successful science parks (Cabral 1998). Albahari et al. (2013), introduced a framework to analyse science park systems (SPSs). Applying it to the Italian and Spanish contexts, they found that science parks played a more essential role in Spain than in Italy because of the more coherent and specific policies supporting the parks, sounder business models, and government intervention in the medium-long term.

Guadix et al. (2016) define successful science parks as those that have overcome initial hurdles to have high land occupation rates, housing firms that generate high revenue and numbers of employees. The availability of R\&D centres and academic institutions encouraging the development of specialised knowledge and knowledge transfer amongst the various stakeholder organisations are crucial in this, as demonstrated in the case of Sophia Antipolis (Barbera and Fassero 2013). Eto (2005) also indicated, however, that technoparks in Japan are often located in rural areas, often distant from train stations, highlighting obstacles to promoting high/new technology park performance. Hu (2007) found, therefore, that most of China's technology parks are located in large core urban areas where technological, educational and industrial resources are also concentrated.

Science park performance can therefore be seen to be at least partly the result of public-private partnerships, with multiple organisations involved in influencing their mission and operational procedures (Phan et al. 2005). Government support is therefore an 
important factor in determining the likelihood of success. For example, studies in Japan (Westhead 1997; Park 2004) have demonstrated the importance of central and local governments in supporting the development of SP through active involvement, national and research institutes, and strategies to promote industrial $R \& D$. Likewise, the success of BIORIO in Brazil was attributed to dynamic government funding, alongside researchorientated institutions and a research orientated private sector (Cabral 1998). Vaidyanathan (2008) also identified the key role of the Indian government's business model, which fostered links between public, private, and foreign sectors. Etzkowitz and Zhou's (2018) conclusion that the success of science parks is at least partly reliant on their being part of broader regional University-Industry-Government interactions also reinforces the importance of the wider RIS to science park success.

Beginning with the broad RIS-University-Science park framework in which innovation takes place, therefore, two basic categories of analysis were identified: (1) the main roles and (2) focus of each of the key stakeholders and the relationships between them.

\subsection{The key role of the RIS in resourcing}

According to Buesa et al. (2006)the RIS acts as a set of public and private organisations forming a network and interacting to create and spread knowledge and innovation within a specific territory. Articles that fall within our study parameters emphasise the importance of this RIS context. Specifically, this context acts as a trigger to defining what can or cannot be achieved. Hence, alongside government support, the university's role and the science park's functions and performance crucially depend on the RIS. The implication being that otherwise these functions will not operate optimally.

The concept of the Regional innovation system (RIS) highlights the importance of a range of institutions, national and local policies in human resource development, local government, and designation of land development, which can include high-tech parks, science and industrial parks (Zhang 2015). This supports interactive learning and helps explain differences in regional innovation performance and economic growth (Asheim and Coenen 2006; Cooke 2002a, 2003). Asheim and Coenen (2005) also identify the importance of fostering "regional culture" in the development of a RIS, dynamics eventuating not only from general economic processes but also sociological circumstances relevant to knowledge production and the uptake of new knowledge (Rip 2002). A dense inter-organisational network within a region is therefore key to encouraging knowledge diffusion, regional learning, and effective resource transfer in RIS (Takedad et al. 2008), specifically when surrounded by supporting innovative agencies (Asheim and Isaksen 2002). Whilst Lew et al. (2018) also highlighted the importance of international connections of regional innovation actors, strong government innovation policy initiatives, and regional R\&D collaboration.

The RIS therefore represents both a context and a resource, where the region is a network of connected actors, built up by regional resources within the network, allowing knowledge to be transferred across agents. (Cantner et al. 2010), with the impact of regional policies in the creation and development of science parks a specific area of analysis suggested by Mora-Valentín et al. (2018). This is supported by strong regional governance, defined as the capacity to develop the policies and organisations required (Cooke and Morgan 1998). To design a sustainable RIS researchers have indicated that resourcing the development of relevant infrastructure is one of the criteria necessary for success, the infrastructure itself an essential determinant for firm location choice (Gerstlberger 2004; Takeda et al. 2008). 


\subsection{The key role of the university in brokering knowledge between the RIS and science park}

Universities have been identified as a major component of the RIS, and they play a crucial role in brokering knowledge (Chung 2002; Gunasekara 2006; Kramer et al. 2011; Lew et al. 2018), which differs to other parts of the RIS. Whilst universities are often crucial actors in their regions in terms of employment and economic activity (Löfsten and Lindelöf 2005), they play an important role as both direct and indirect sources of knowledge production, which they are able to feed or diffuse into the RIS (Cooke 2002a, b; Lew et al. 2018).

Universities are therefore specifically important in both the knowledge generation and diffusion subsystem of RIS, as well as subsequent knowledge application activities and connections with firms that aim to exploit the knowledge for commercial returns (Cooke 2002a). It is in this exploitation role, however that science parks can be seen to have a specific role in conjunction with universities.

\subsection{The key role of the science park in exploiting innovation}

The science park can therefore be seen to play the role of a catalytic incubator environment for transformation of pure research into production. Authors such as Feldman (2007) highlight the role of science parks in innovation exploitation (Huang et al. (2012), potentially generating smaller (Staudt et al. 1994) or larger (Storey and Tether 1998) benefits in terms of employment growth as well as via better sales and sales growth performance (Gwebu et al. 2019). More specifically for SME's they have been identified as regional growth engines (Cheng et al. 2014) creating wealth and high value job opportunities through technology based-research and development (Chang et al. 2010).

Science parks also offer a social environment where proximity between firms supports key information transfer for the development of innovation (Fernández-Alles et al. 2014). Within science parks, firm proximity can enhance the interaction between personnel and extend the networking to support the development of innovation, as seen in the case of Hsinchu Science-based Industrial Park (HSIP) and Tainan Science-based Industrial Park (TSIP) (T.-S. Hu 2008). In addition, science parks can be used by the government to promote innovation in specialised sectors in specific localities, either in single sectors (e.g. biotechnologies in agro-food industry in Lombardy (Bosco 2007) or multiple related hightech sectors in Hsinchu Science park (Chen et al. 2006). Connection between science parks could also form allowing greater exchange of knowledge in specialised sectors (Yang et al. 2009).

\subsection{The Interrelationships between RIS, University and Science Park}

Science parks also, however, utilize the physical and network infrastructure created through the RIS, alongside their relationships with the universities that support them, to facilitate flows of knowledge with the potential of commercialisation into new firms created on the science park itself to produce innovation exploitation outcomes. Thus, science parks can also be defined as intermediate structures which established around universities e.g. IDEON (Angelakis and Galanakis 2017) or brokerage intuitions that attract firms and other 
organisations for cooperation (Almeida et al. 2011) or innovation support infrastructure (Diaz-Puente et al. 2009; Doloreux and Dionne 2008) or facilitators of inter-organisational relationships (Pilar Latorre et al. 2017).

However, whilst Lenger (2008) found that for technoparks (or science parks) and university-industry joint research centres, universities are key actors, making significant contribution to RIS, the roles and interactions of science parks as well as a numbers of parks differ according to the specific RIS. For instance, Huang and Fernández-Maldonado (2016) found that in the Eindhoven city-region, each science park focused on a single field of R\&D facilitating the clustering of relevant industries and acting as a hub for the regional economy. Conversely, where there is only one science park in a region, this must more broadly support regional technological strengths. For example, where this situation exists in the Beauce region of Canada, this highlights the 'institutional thinness' characteristic of peripheral regions (Doloreux 2004). Gebauer et al. (2005) also demonstrate that the multiple small innovation centres in more rural/economically peripheral areas of Western Germany often lack critical mass because of the localities in which they are located. Lecluyse et al. (2019) identified a need for more research into the relationship between economic geography and science park when analysing the contribution of the science park to the economy, Gkypali et al. (2016) suggesting that the science park needs to orientate itself within the RIS in which it finds itself.

The preceding discussion also highlights, however, that whilst the RIS, universities and science parks have different roles in the innovation process, there are also clear, strongly overlapping relationships through which these roles are displayed. We utilise the linear approach (e.g. Massey and Wield 2006; Quintas et al. 1992; Westhead 1997), as an initial simplifying framework to structure the sections that follow (see Fig. 1), whilst also identifying the overlapping two-way relationships between activities.

Respectively, these sections discuss: (1) The university-RIS relationship which demonstrates an emphasis of activities on the dissemination of basic research, (2) the RIS-University-Science Park relationship emphasising product development activities, and (3) the Science Park-University relationship, which in which the emphasis is on applied research.

\subsubsection{The university-RIS relationship and its focus on basic research for dissemination}

Rip (2002) emphasized how universities have evolved to more closely support both regional innovation systems and strategic science, which can also be seen as constituting basic research. Rip's (2002) case study analysis of the University of Twente in the

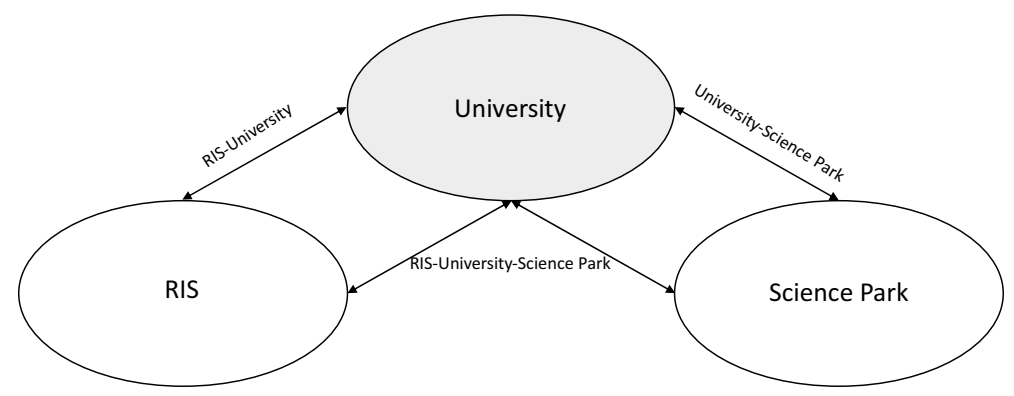

Fig. 1 The sets of RIS-university-science park relationships 
Netherlands found; "The University of Twente has a strong regional orientation, but that its spin-offs strengthen the economy, not necessarily the regional innovation system. It is also prominent (in selected areas) at the international research frontier. Promising options are a key feature of strategic science, but their 'promise' most often is not defined in regional terms, but in relation to a global scientific and technological frontier." (p. 129).

The interaction between the university and other RIS actors can be seen as "knowledge co-creation' (Gunasekara 2006). In this scenario, universities have the main role of coordinating the production of knowledge and disseminating it to other actors in the RIS, but universities also cooperating with regional firms to undertake collaborative projects to conduct the basic research and create the new knowledge. The relationships between the university, the wider RIS and science park actors can then be viewed as 'conduits' for knowledge flows within entrepreneurial RIS (Yoon et al. 2015). The science park in this type of relationship fosters linkages between the university and the other RIS actors, enhancing product development and commercialising products. The last relationship occurs specifically between the university and science park actors. Defined as 'inter-organisational relations' (Gunasekara 2006), many subtypes of links may exist. More linkages are created the more organisations are involved, including the government, researchers, firms, policymakers, business ventures, and so on.

Whilst the focus for basic research for dissemination is through relationships between the university and key stakeholders, and theoretically includes the processes of knowledge co-creation, acting as conduit, and interorganizational relationship building, several studies also suggest weaknesses in Universities' abilities to enhance the RIS through these mechanisms. Gunasekara's (2006) undertook an analysis of three Australian universities, utilising a conceptual framework based on the triple helix model, literature on university engagement, and innovation systems. This research found the universities to be weak in their willingness and capability to act like industry, generating poor commercial benefits. In Daedeok Innopolis, universities were also found to have strong links with public research institutions, but weaker links were demonstrated between firms and universities (Yoon et al. 2015). Hence universities are often perceived to be relatively weak in this aspect as a result of a greater focus on education over those activities of most relevance within many RIS, specifically R\&D activities which are closer to market (as opposed to basic research). It was these weaknesses that led Chung (2002) to suggest the need for policies supportive to innovation, such as the recruitment of experienced professors and collaboration between academics and researchers in research centres. It is also in this context that the science parks can be seen as helping to facilitate a better flow of university generated knowledge into innovation.

\subsubsection{The RIS-university-science park relationship and its focus on product development}

Many governments globally have used science parks to stimulate the regional economy by fostering the growth of NTBFs and science-based industry. For example, the government of Taiwan established science parks, officially defined as offshore economic zones, with complementary business services and financial incentives provided to high-technology manufacturers (Tsai et al. 2007). To date, however, there have been only a limited number (6) of studies focusing on science parks whilst also incorporating the RIS, four of these six papers also discussing the role of the university within this context with each taking a different focus.. 
For Zhang (2015) the concept of the RIS itself identified the importance of institutions, human resource and land development, which included science parks. Zhu and Tann (2005), viewed the science park as an RIS in its own right, as well as playing roles and interacting with the university to help develop the wider RIS. Hommen et al. (2006) found a specifically important role in the Swedish context for university education, training and intellectual property management to the development of the RIS. For Jonsson (2002), the role of the university was specifically important in developing and supporting communication in RIS networks, whilst for Yoon et al. (2015) the building of formal and informal relationships in the RIS by universities was of particular relevance. Given these different foci Gkypali et al. (2016) identify the need to place the science park in its specific RIS context. The limited number of papers identified, however, both generally, and within the university category, as well as the disparate focus of these papers, again highlights the lack of studies in this specific area.

Taking a broader perspective, for universities to become more effective in their RIS the knowledge they supply must fit with the needs of their region's firms and raise future interest in their services, through product development (e.g. Tödtling and Kaufmann 2002). Consequently many universities have set up science parks and incubation centres to help firms overcome obstacles in the innovation process and strengthen university-industry interactions (Asheim and Coenen 2006; Gunasekara 2006; Malairaja and Zawdie 2008; Vedovello 2002). These are supported by Technology Transfer Offices (TTOs), which require close proximity and systemic links between university and industry.

Science parks are also viewed as policy instruments for encouraging regional development, innovation, and the setting up of new firms through networks between higher educational institutions (HEIs) and industry (Hansson et al. 2005; T.-S. Hu et al. 2005). In particular policy makers see science parks as "meta-organisations", important in the task of getting small and medium-sized enterprises to participate more closely in knowledge creation with universities and research institutions (Giaretta 2013). This underlines the importance of the science park in terms of promoting links with the university, with the aim of making contributions to the regional economy. Indeed, Zhu and Tann (2005) analysed Zhongguancun science park (ZSP) investigated the linkages and the knowledge flows between several actors of ZSP as a RIS in itself, viewing the park effectively as a RIS in itself, acting as: " $a$ social system consisting of different sets of clusters, which interact with different linkages and flows, in a systematic way, to enhance the localized learning and competitive capabilities of a region". In this context, science parks form an important component in the broader government supported RIS. They are seen as a tool of regional development policy through transferring university generated public knowledge to NTBFs, through product development within regional contexts (Fukugawa 2006; Vedovello 2002).

\subsubsection{The science park-university relationship and its focus on applied research}

There is much research focused on the role that the science park plays in bridging the gap between university and industry (Bakouros et al. 2002; Malairaja and Zawdie 2008; Phillimore 1999; Quintas et al. 1992; Vedovello 2002), though there is much less focus in the literature on the developing economy context when compared to more developed economy examples. As outlined previously, science parks are conceived as a mechanism to help link research results from universities more closely to the market and stimulating technological spillovers (Löfsten and Lindelöf 2005; Siegel et al. 2003a). Consequently, for Universities 
the main aim of establishing science parks is to exploit their R\&D results, research ideas, and secure funding for future research (Hansson et al. 2005).

Proximity between knowledge creators in the university and firms on the science park can also be seen, in a range of geographical contexts, to be important to the attractiveness and growth of science parks (Guy 2002; Ma 1998; Siegel et al. 2003b; Pálmai 2004; Fikirkoca and Saritas 2012; Link and Scott 2003a; Ratinho and Henriques 2010). These links can be divided into forms: formal (e.g. licensing and co-operative alliances), and informal (e.g. personal relations, business partners, family tie and the mobilisation of personnel) (Bakouros et al. 2002; Dettwiler et al. 2006; Lindelöf and Löfsten 2004; Westhead and Batstone 1998). The advantages of close linkages identified within the literature include: access to experts providing improved performance (Dierdonck et al. 1991; Lindelöf and Löfsten 2004; Vedovello 2002), providing the latest knowledge (Markman et al. 2005; McAdam and McAdam 2008), encouraging R\&D activities amongst firms (Siegel et al. 2003a), and maintaining and supporting industrial innovation (Hu 2008).

In addition to the receipt of academic knowledge, a number of other factors have been found to influence firm decisions to locate in Science parks. For example, Westhead and Batstone (1998) found that many NTBFs decided to establish or relocate onto science parks because of the "prestige and overall image of the site" and the "prestige of being linked to a HEI/centre of research". A case study of the Tsinghua University Science Park also revealed the significance of reputational benefits from being located on the park to firms (Motohashi 2013). The links between academia and industry within science parks are therefore complex, with Hobbs et al. (2017) arguing for further development of the literature. For Universities, however, proximity to a science park can also fundamentally shift their mission from basic to applied research (Link and Scott 2003b).

\section{The changing roles of the university in the RIS-university-science park nexus}

The analysed literature identifies the university as sitting at the centre of a RIS-universityScience park nexus. The University plays an important specific role in its own right as a knowledge broker. It also further contributes through its relationships with the RIS and science park, as these relate to a university's potential basic research, dissemination and applied research activities. The university's focus therefore changes, depending on these relationships. Specifically, in addition to directly brokering knowledge, it plays supporting roles with regards to resourcing and innovation commercialization. Our subsequent analysis therefore focuses on the second question, namely: how do the roles of the university change through its interrelationships within the RIS and with the science park? This is summarised in Fig. 2 below.

Details of the empirical evidence from the systematic literature review is summarized in the Tables 7, 8, 9 below, exploring more fully: (1) the parties involved and how the activities associated with specific inter-relationships and (2) the specific importance of the university in terms of resource sharing, brokerage, and exploitation/commercialisation.

Developing upon the preceding discussions, and following an initially linear approach to framing (though recognising and identifying the potentially .6overlapping multi-directional nature of the concepts), the literature in the tables below is initially conceptualized within an innovation "pipeline" reflecting the three different roles performed by the University both singly and through its relationships with the RIS and 


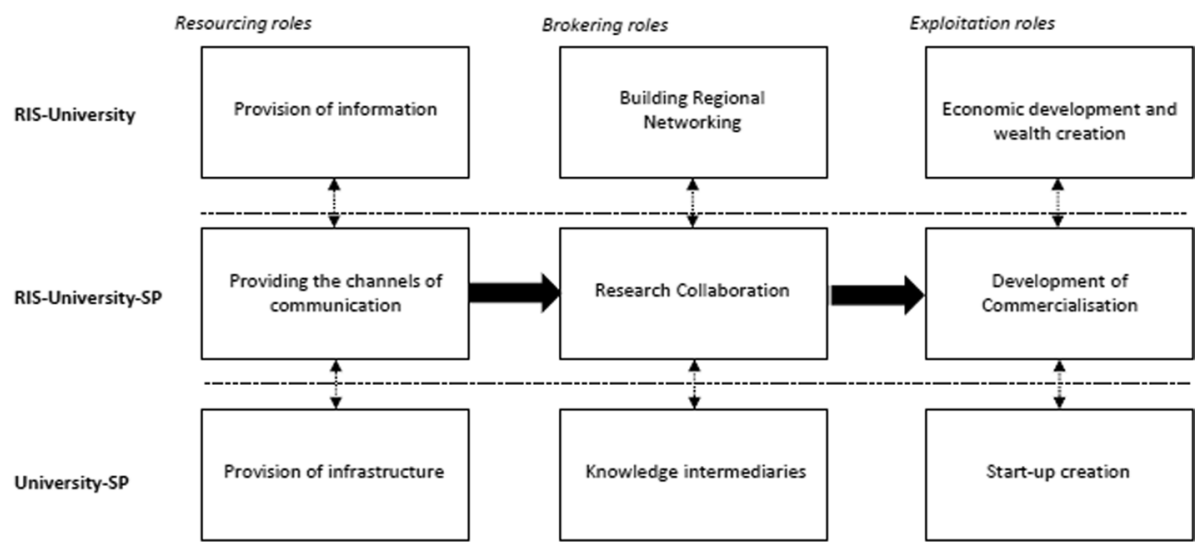

Fig. 2 Roles of the university in the RIS-university-science park nexus

science park. First, "Resource sharing", includes the offering, facilitating, and supporting of research results, data, and information that the university produced for others actors within the RIS. Secondly, the central University "Brokerage role" encompasses the University acting as a "seedbed", creating conditions to promote innovation as an incubator facilitating the transfer of knowledge, encouraging the spin-offs, and stimulating the production of innovation (Felsenstein 1994). The final role, "exploitation and commercialization", involves activities making use of and benefiting from these resources and brokering activities to assist economic development through innovative products. These are exploited through commercialization processes within the science park to produce commercial returns, which further strengthens the businesses utilizing them and the regional innovation systems in which they sit.

\subsection{Resource sharing roles}

At its interface with the RIS actors the University shares data and knowledge, and thus performs a role in the 'provision of information' (see Table 7). In this function the University itself produces knowledge, it has connections with firms to create and generate new knowledge by conducting research, and shares knowledge or data with firms through university programmes or specific courses (e.g. Hommen et al. 2006; Looy et al. 2003).

Secondly, in its relationship between the science park and RIS, the University then provides channels of communication. Here the University can play a key role in creating networks, as well as helping to ensuring and optimizing communication and cooperation between the key actors (e.g. Jonsson 2002; Watkins-Mathys and Foster 2006). This can play a key role in the transfer of tacit knowledge through a varied network of actors (e.g. Looy et al. 2003; Zou and Zhao 2013). This occurs through conferences, meetings, exhibitions, social networks, as well as firms interactions with students, staff and researchers who have the specialized skills consistent with industrial needs. The final resource sharing role highlights the sharing of infrastructure between the University and Science Park. Here Universities have been identified as providing a range of general facilities, alongside specific tools and specialist laboratory equipment (e.g. Bass 1998; Sofouli and Vonortas 2007). 


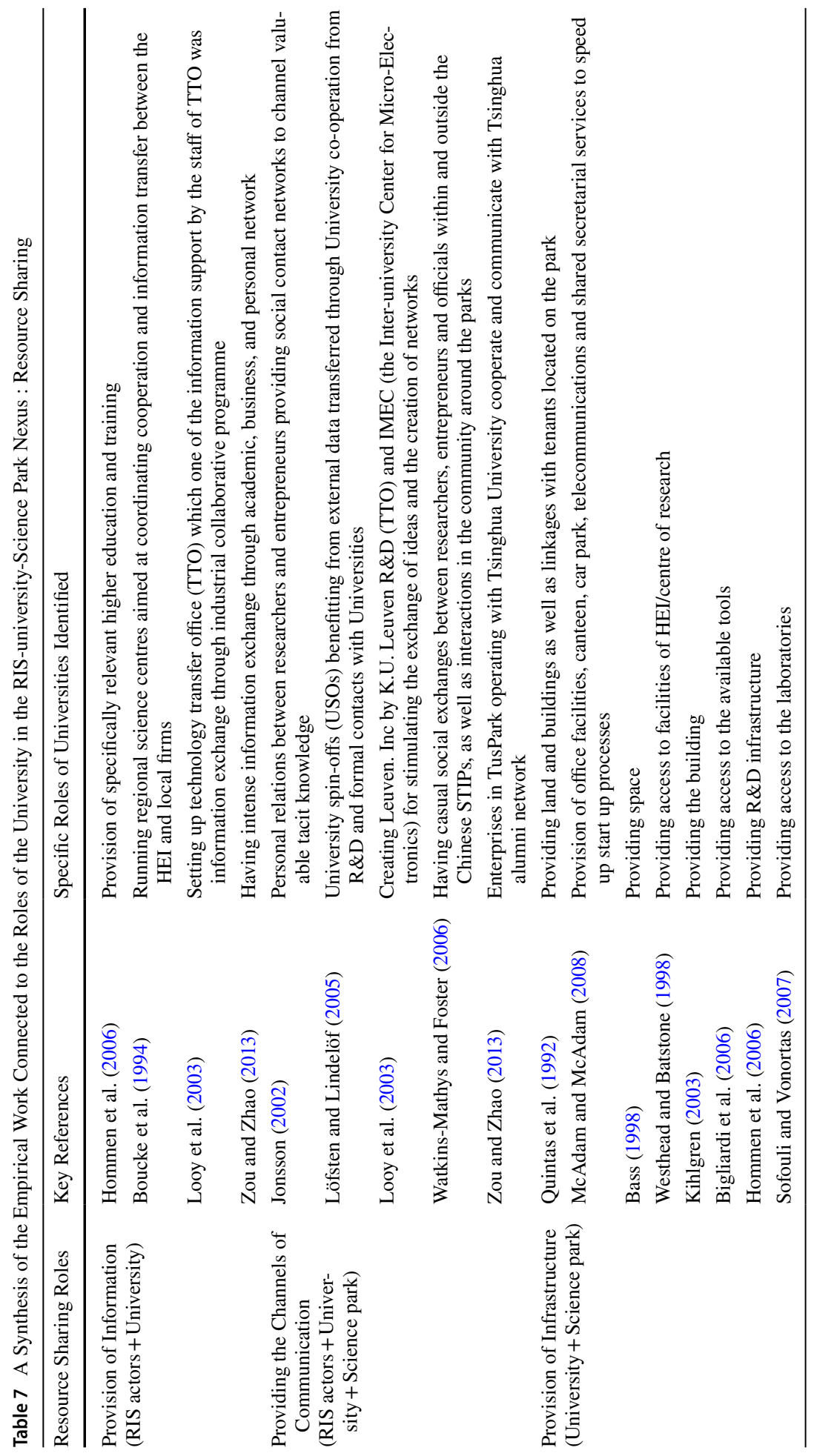




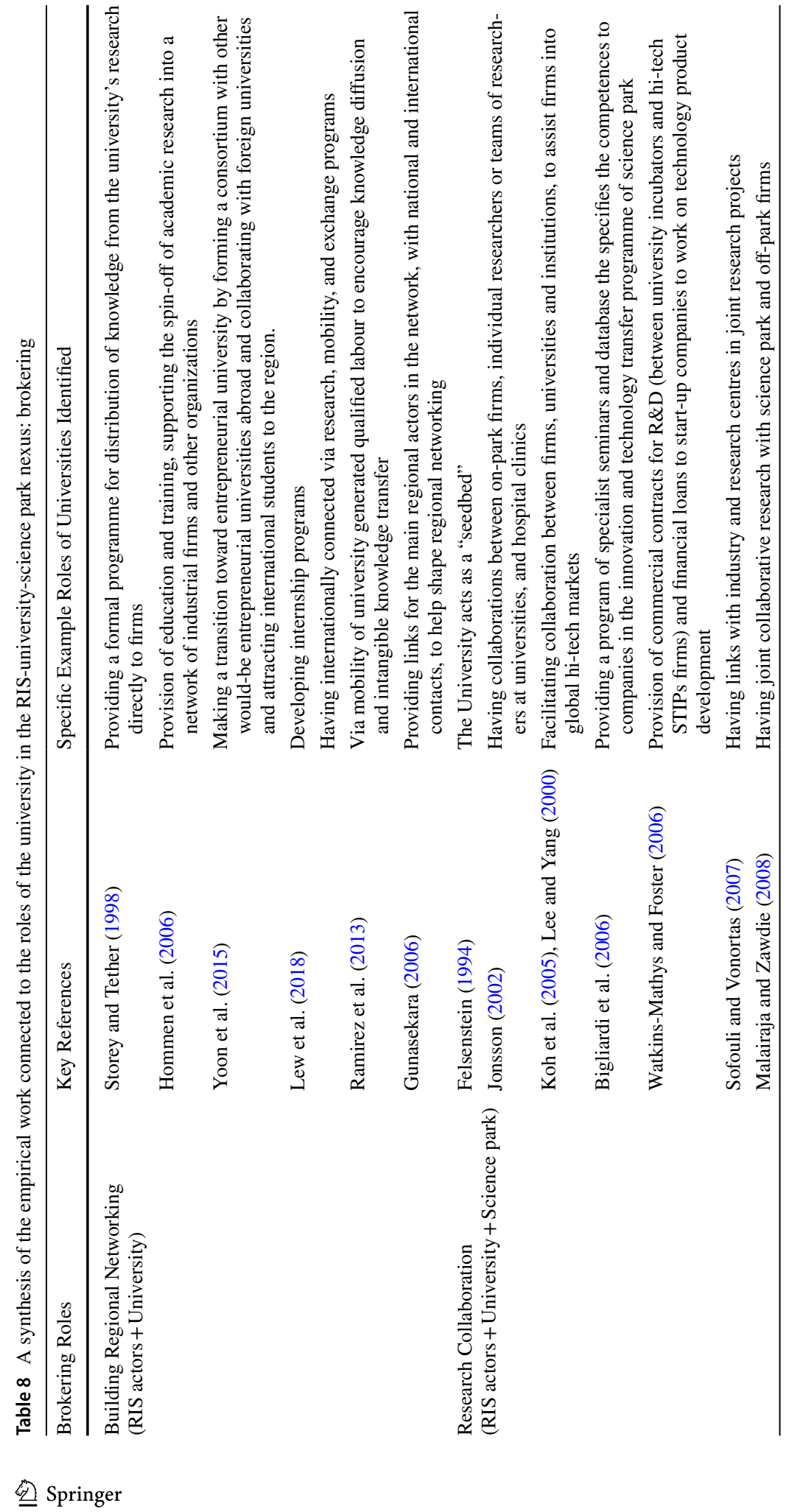




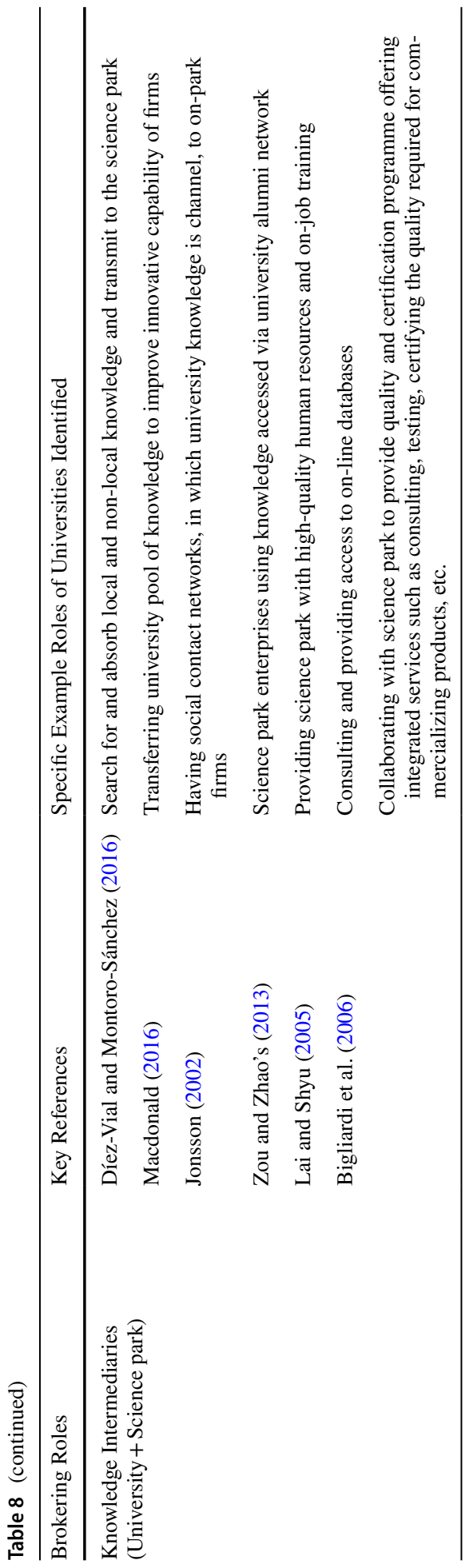




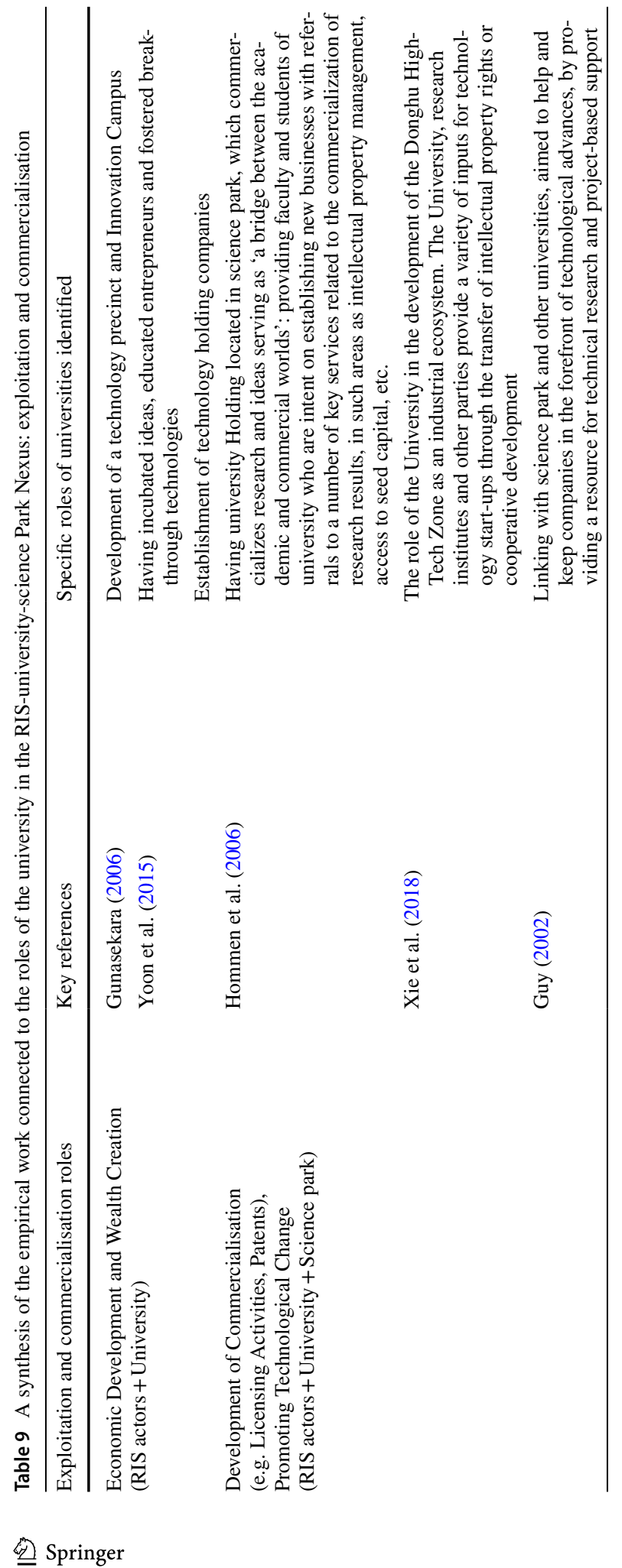




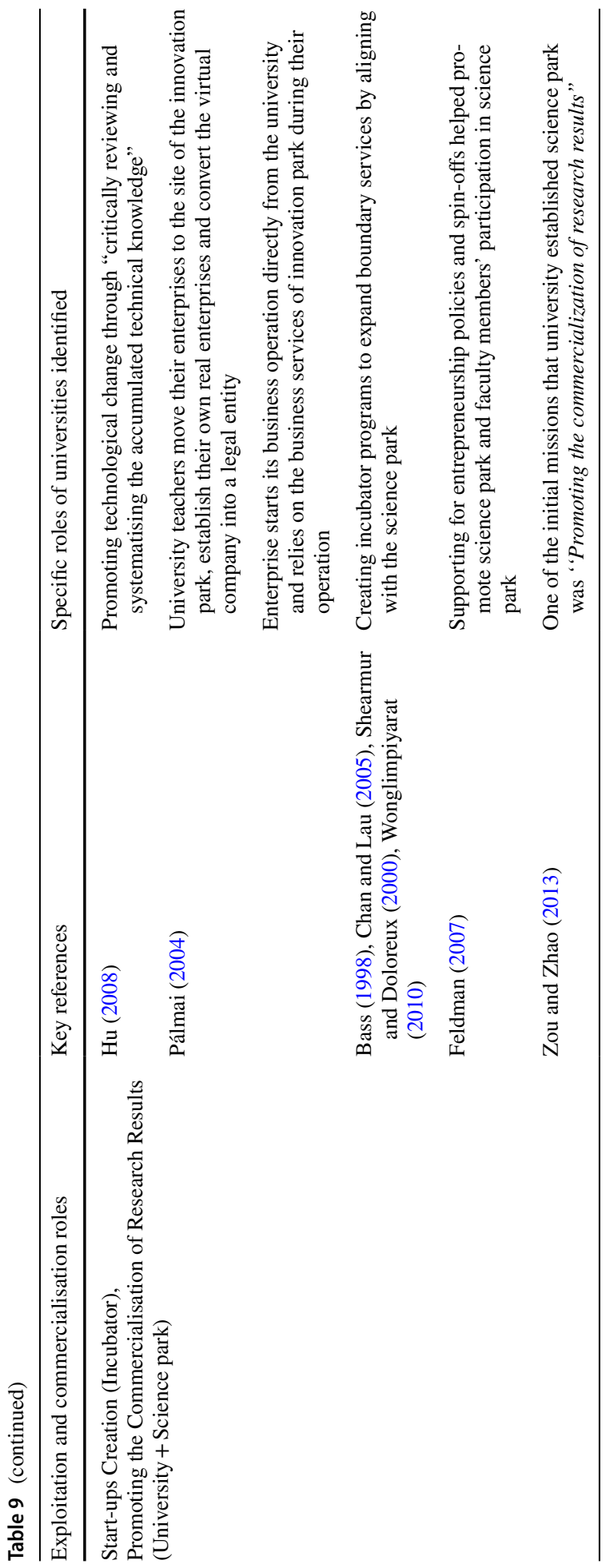




\subsection{Brokerage roles}

The first Brokerage function performed by the University focuses on building regional networking with and between the other actors within the RIS. For example, through labour mobility, contacts and supportive strategy and policy (Table 8). In the University's second brokering role it supports interactions to create and promote innovation between the university, science park, and other actors in RIS. Research collaborations between these actors are considered crucial in this, and across a number of industries R\&D collaboration between them is highly valued (Kramer et al. 2011). For firms and the RIS, University's investments in R\&D provide benefits that can contribute to their innovation processes (Barra and Zotti 2018), whilst the University benefits from R\&D collaboration through additional income and experience of firms' real-life problems (Harper and Georghiou 2005). Finally, within the science park itself the University can then act as a "knowledge intermediary". In this role the university can search for and absorb local and non-local knowledge and then transmit this knowledge to the science park, to improve the innovative capability of firms (e.g. Díez-Vial and Montoro-Sánchez 2016). This role is increasingly promoted by government to encourage technology transfer and regional development due to it supporting the geographical clustering of firms (Tan 2006).

\subsection{Exploitation and commercialisation roles}

In terms of RIS-University relationships, the role of the university also includes directly increasing local economic development (e.g. see $\mathrm{Hu}$ et al. 2005). This is achieved through vehicles such as technology companies and innovation campuses (see Table 9). The second exploitation and commercialization role of the University focuses on its simultaneous relationships with the science park and RIS actors (e.g. see Looy et al. 2003). Given that firms' in science parks primary purpose is to launch new products and develop markets (Löfsten and Lindelöf 2003), the university's role in commercialization is essential and often supported by specific government policies (Mian et al. (2016). This effort is focused through the development of vehicles for commercialisation (e.g. licensing, patents), as well as more broadly promoting technological change.

In the final exploitation and commercialization role, Universities increasingly participate directly in the commercialization of knowledge via licensing activities and spinoff firms (Looy et al. 2003). The study of Sofouli and Vonortas (2007) supports this notion in their case study of S\&T Parks and business incubators of Greece, especially, in the first policy wave (1990's) government providing funding support for establishing parks by universities and other public research institutes in order to exploit R\&D results. Spin-off firms are also then seen as crucial in the development of universityindustry relationships and as a tool for valorisation of research results (Salvador 2011). Indeed, Hansson et al. (2005) further claim that universities expect science parks to help them commercialise their research ideas and secure funding for further research (Hansson et al. 2005). 


\section{Conclusions, research gaps and implications}

The overall aim of this review was to analyse the roles of the university in the RIS actors-university-science park nexus. Whilst it is clear that Universities contribute to both science parks and the RIS, the particular roles they perform for the RIS actors or science park have not been systematically examined. Furthermore, how these basic roles differ between each actor remains ambiguous.

Within this review we have attempted to contribute by focusing on these shortcomings. Specifically, bringing the literature on science parks and RIS together, we have contributed to this field by identifying how the university's key roles change as it moves between: RIS actors-university, RIS actors-university-science park, and university-science park interrelationships. Further, moving beyond basic views of the roles performed by the university (Massey and Wield 2006; Quintas et al. 1992; Westhead 1997), we have specifically distinguished between three different types of activities performed by the university within each of these three types of interactions: knowledge co-creation, acting as conduit, and inter-organisational relationship building. In doing so, we have highlighted how the key basic roles of the university change as these different dimensions interact, thereby making a contribution.

Further research is however, required to provide a more finely grained understanding of the roles performed by the university within each of these relationships, and how their contributions can be optimized in different contexts. Our review also reveals a series of important gaps in the literatures on science parks and RIS. In terms of the science park literature, for example, no general theory of the science park was observed due to the origins of the parks being different depending on a range of factors and the context of the country.

Whilst a broad identification of the roles of the university in the RIS actors-university-science park nexus is possible from the existing literature, an examination of these roles within specific national or regional context is therefore critical in order to identify how this affects the relative significance of specific roles. Our review also supports that of Lecluyse et al. (2019) which identified a need for more research into the relationship between science park and region the science park is located within, in order to more fully explore the roles and contribution the science park can make. In addition, the impact of regional policies in the creation and development of science parks should also be analysed as suggested by (Mora-Valentín et al. 2018).

Our review therefore supports Hobbs et al. (2017) who argued that the science and technology park literature can still be considered to need further development, a situation that can be seen to be particularly the case in the context of peripheral developing economies. More specifically, our review has revealed a strong imbalance in the geographic distribution of prior studies, with the majority having been conducted in developed countries and core regions. By contrast developing countries and more peripheral regions have been relatively overlooked, peripheral regions in developing economies particularly so.

Considering the multiplicity of roles performed within the RIS-University-Science park nexus, there is therefore a clear gap in the literature with respect to both university roles and potential contributions within nascent peripheral and developing economy RIS. In particular, there is a specific need to understand how universities are able to contribute to the development of RIS within developing countries, as well as identifying the activities they are less capable of performing due to shortcomings in the RIS as well as their own capabilities. 
More broadly, although the university is found to be the crucial component in both RIS and science park literature, there were only a limited number of studies focused on the simultaneous roles played by the university during its relationships with these other actors. Consequently, future research needs to provide a more integrated approach to further our understanding of the simultaneous roles of universities within these relationships, which again will have specific national and regional contexts. This would also help further our understanding of the university's role as conduit between the RIS and Science Park.

Methodologically there also appeared to be relatively few studies conducted longitudinally, or comparatively. We therefore suggest a need for comparative studies to better uncover the relative influence of regional contexts, specific policies, and capabilities of Universities on the specific roles they perform. This may include analysis of Science Parks where universities are/are not present, to further understand their roles, as well as examples of science parks where universities successfully contribute versus those where universities make less of a contribution.

Finally, few studies simultaneously linked the literature on the science park with that of the RIS, identifying the necessity to examine the roles of specific universities in science parks within the context of specific RIS. Overall, this identifies the need for contextual studies to explore these roles and unpick the impact of specific local and regional government initiatives on the roles and contributions of the University. Such research would help to inform future policy to enhance science park performance and ultimately the development of RIS in a manner appropriate for a particular context.

In conclusion, whilst Universities can make several contributions within the RIS-University-Science park nexus their ability to undertake activities that are closer to the market have been found to be limited in several respects, not only because of their own limitations but also because of the wider RIS context in which they operate. The takeaway message for policymakers, universities and science park managers, therefore, is that, in the science park context, the results of this review suggest that universities will be assisting science parks to play different combinations of roles in relation to innovation, depending on the different RIS contexts in which they find themselves.

Open Access This article is licensed under a Creative Commons Attribution 4.0 International License, which permits use, sharing, adaptation, distribution and reproduction in any medium or format, as long as you give appropriate credit to the original author(s) and the source, provide a link to the Creative Commons licence, and indicate if changes were made. The images or other third party material in this article are included in the article's Creative Commons licence, unless indicated otherwise in a credit line to the material. If material is not included in the article's Creative Commons licence and your intended use is not permitted by statutory regulation or exceeds the permitted use, you will need to obtain permission directly from the copyright holder. To view a copy of this licence, visit http://creativecommons.org/licenses/by/4.0/.

\section{References}

Acs, Z. J., Braunerhjelm, P., Audretsch, D. B., \& Carlsson, B. (2009). The knowledge spillover theory of entrepreneurship. Small Business Economics, 32(1), 15-30. https://doi.org/10.1007/s1118 7-008-9157-3.

Albahari, A., Catalano, G., \& Landoni, P. (2013). Evaluation of national science park systems: A theoretical framework and its application to the Italian and Spanish systems. Technology Analysis \& Strategic Management, 25(5), 599-614. https://doi.org/10.1080/09537325.2013.785508.

Albahari, A., Pérez-Canto, S., Barge-Gil, A., \& Modrego, A. (2017). Technology parks versus science parks: Does the university make the difference? Technological Forecasting and Social Change, 116, 13-28. https://doi.org/10.1016/j.techfore.2016.11.012. 
Almeida, A., Figueiredo, A., \& Silva, M. R. (2011). From concept to policy: Building regional innovation systems in follower regions. European Planning Studies, 19(7), 1331-1356. https://doi. org/10.1080/09654313.2011.573140.

Alshumaimri, A., Aldridge, T., \& Audretsch, D. B. (2017). The university technology transfer revolution in Saudi Arabia. In Universities and the Entrepreneurial Ecosystem (pp. 112-124). https://doi. org/10.1007/s10961-010-9176-5.

Angelakis, A., \& Galanakis, K. (2017). A science-based sector in the making: The formation of the biotechnology sector in two regions. Regional Studies, 51(10), 1542-1552. https://doi.org/10.1080/00343 404.2016.1215601.

Appold, S. J. (2004). Research parks and the location of industrial research laboratories: An analysis of the effectiveness of a policy intervention. Research Policy, 33(2), 225-243. https://doi.org/10.1016/ S0048-7333(03)00124-0.

Asheim, B. T., \& Coenen, L. (2005). Knowledge bases and regional innovation systems: Comparing Nordic clusters. Research Policy, 34(8), 1173-1190. https://doi.org/10.1016/j.respol.2005.03.013.

Asheim, B. T., \& Coenen, L. (2006). Contextualising regional innovation systems in a globalising learning economy: On knowledge bases and institutional frameworks. Journal of Technology Transfer, 31(1), 163-173. https://doi.org/10.1007/s10961-005-5028-0.

Asheim, B. T., \& Isaksen, A. (2002). Regional innovation systems: The integration of local "sticky" and global "ubiquitous" knowledge. Journal of Technology Transfer, 27(1), 77-86. https://doi. org/10.1023/A:1013100704794.

Bakouros, Y. L., Mardas, D. C., \& Varsakelis, N. C. (2002). Science park, a high tech fantasy?: An analysis of the science parks of Greece. Technovation, 22(2), 123-128. https://doi.org/10.1016/S0166 -4972(00)00087-0.

Barbera, F., \& Fassero, S. (2013). The place-based nature of technological innovation: The case of Sophia Antipolis. Journal of Technology Transfer, 38(3), 216-234. https://doi.org/10.1007/s1096 1-011-9242-7.

Barra, C., \& Zotti, R. (2018). The contribution of university, private and public sector resources to Italian regional innovation system (in)efficiency. Journal of Technology Transfer, 43(2), 432-457. https://doi. org/10.1007/s10961-016-9539-7.

Bass, S. J. (1998). Japanese research parks: National policy and local development. Regional Studies, 32(5), 391-403. https://doi.org/10.1080/00343409850116808.

Bigliardi, B., Dormio, A. I., Nosella, A., \& Petroni, G. (2006). Assessing science parks' performances: Directions from selected Italian case studies. Technovation, 26(4), 489-505. https://doi.org/10.1016/j. technovation.2005.01.002.

Bosco, M. G. (2007). Innovation, R\&D and technology transfer: Policies towards a regional innovation system The case of Lombardy. European Planning Studies, 15(8), 1085-1111. https://doi. org/10.1080/09654310701448246.

Boucke, C., Cantner, U., \& Hanusch, H. (1994). "Technopolises" as a policy goal: A morphological study of the Wissenschaftsstadt Ulm. Technovation, 14(6), 407-418. https://doi.org/10.1016/01664972(94)90019-1.

Buesa, M., Heijs, J., Pellitero, M. M., \& Baumert, T. (2006). Regional systems of innovation and the knowledge production function: The Spanish case. Technovation, 26(4), 463-472. https://doi.org/10.1016/j. technovation.2004.11.007.

Cabral, R. (1998). Refining the Cabral-Dahab science park management Paradigm. International Journal of Technology Management, 16(8), 813-818. https://doi.org/10.1504/ijtm.1998.002694.

Cantner, U., Meder, A., \& Ter Wal, A. L. J. (2010). Innovator networks and regional knowledge base. Technovation, 30(9-10), 496-507. https://doi.org/10.1016/j.technovation.2010.04.002.

Chan, K. F., \& Lau, T. (2005). Assessing technology incubator programs in the science park: The good, the bad and the ugly. Technovation, 25(10), 1215-1228.

Chan, K. Y. A., Oerlemans, L. A. G., \& Pretorius, M. W. (2010). Knowledge exchange behaviours of science park firms: The innovation hub case. Technology Analysis \& Strategic Management, 22(2), 207228. https://doi.org/10.1080/09537320903498546.

Chang, S. L., Lee, Y. H., Lin, C. Y., \& Hu, T. S. (2010). Consideration of proximity in selection of residential location by science and technology workers: Case Study of Hsinchu, Taiwan. European Planning Studies, 18(8), 1317-1342. https://doi.org/10.1080/09654313.2010.490651.

Chen, C. J., Wu, H. L., \& Lin, B. W. (2006). Evaluating the development of high-tech industries: Taiwan's science park. Technological Forecasting and Social Change, 73(4), 452-465. https://doi. org/10.1016/j.techfore.2005.04.003. 
Cheng, F., van Oort, F., Geertman, S., \& Hooimeijer, P. (2014). Science parks and the co-location of hightech small- and medium-sized firms in China's Shenzhen. Urban Studies, 51(5), 1073-1089. https:// doi.org/10.1177/0042098013493020.

Chordà, I. M. (1996). Towards the maturity stage: An insight into the performance of French technopoles. Technovation, 16(3), 143-152. https://doi.org/10.1016/0166-4972(95)00042-9.

Chung, S. (2002). Building a national innovation system through regional innovation systems. Technovation, 22(8), 485-491. https://doi.org/10.1016/S0166-4972(01)00035-9.

Colombo, M. G., \& Delmastro, M. (2002). How effective are technology incubators? Research Policy, 31(7), 1103-1122. https://doi.org/10.1016/s0048-7333(01)00178-0.

Cooke, P. (2002a). Regional innovation systems, clusters, and the knowledge economy. Industrial and Corporate Change, 10(4), 945-974. https://doi.org/10.1093/icc/10.4.945.

Cooke, P. (2002b). Regional innovation systems: General findings and some new evidence from biotechnology clusters. Journal of Technology Transfer, 27(1), 133-145. https://doi.org/10.1023/A:1013160923 450.

Cooke, P., Gomez Uranga, M., \& Etxebarria, G. (2003). Regional innovation systems: Institutional and organisational dimensions. Research Policy, 26(4-5), 475-491. https://doi.org/10.1016/s0048 -7333(97)00025-5.

Cooke, P., \& Morgan, K. (1998). The associational economy: Firms, regions, and innovation. Oxford: Oxford University Press.

Corsaro, D., \& Cantù, C. (2015). Actors' heterogeneity and the context of interaction in affecting innovation networks. Journal of Business and Industrial Marketing, 30(3-4), 246-258. https://doi.org/10.1108/ JBIM-12-2014-0249.

Dettwiler, P., Lindelöf, P., \& Löfsten, H. (2006). Utility of location: A comparative survey between small new technology-based firms located on and off Science Parks-Implications for facilities management. Technovation, 26(4), 506-517. https://doi.org/10.1016/j.technovation.2005.05.008.

Diaz-Puente, J., Cazorla, A., \& de los Rios, I. (2009). Policy support for the diffusion of innovation among SMEs: An evaluation study in the Spanish Region of Madrid. European Planning Studies, 17(3), 365-387. https://doi.org/10.1080/09654310802618028.

Díez-Vial, I., \& Fernández-Olmos, M. (2015). Knowledge spillovers in science and technology parks: How can firms benefit most? Journal of Technology Transfer, 40(1), 70-84. https://doi.org/10.1007/s1096 1-013-9329-4.

Díez-Vial, I., \& Fernández-Olmos, M. (2017). The effect of science and technology parks on firms' performance: How can firms benefit most under economic downturns? Technology Analysis \& Strategic Management, 29(10), 1153-1166. https://doi.org/10.1080/09537325.2016.1274390.

Díez-Vial, I., \& Montoro-Sánchez, Á. (2016). How knowledge links with universities may foster innovation: The case of a science park. Technovation, 50-51, 41-52. https://doi.org/10.1016/j.technovati on.2015.09.001.

Doloreux, D. (2004). Regional innovation systems in Canada: A comparative study. Regional Studies, 38(5), 481-494. https://doi.org/10.1080/0143116042000229267.

Doloreux, D., \& Dionne, S. (2008). Is regional innovation system development possible peripheral regions? Some evidence from the case La Pocatière, Canada. Entrepreneurship and Regional Development, 20(3), 259-283. https://doi.org/10.1080/08985620701795525.

Durão, D., Sarmento, M., Varela, V., \& Maltez, L. (2005). Virtual and real-estate science and technology parks: A case study of Taguspark. Technovation, 25(3), 237-244. https://doi.org/10.1016/S0166 $-4972(03) 00110-X$.

Eto, H. (2005). Obstacles to emergence of high/new technology parks, ventures and clusters in Japan. Technological Forecasting and Social Change, 72(3), 359-373. https://doi.org/10.1016/j.techf ore.2004.08.008.

Etzkowitz, H., \& Leydesdorff, L. (1996). Introduction: Universities in the Global Knowledge Economy Triaple Helix of University-Industry-Government Relations. Retrieved from https://papers.ssrn.com/sol3/ papers.cfm?abstract_id=2932054.

Etzkowitz, H., \& Leydesdorff, L. (1999). The future location of research and technology transfer. The Journal of Technology Transfer, 24(2-3), 111-123. https://doi.org/10.1023/A:1007807302841.

Etzkowitz, H., \& Leydesdorff, L. (2000). The dynamics of innovation: From National Systems and "mode 2" to a Triple Helix of university-industry-government relations. Research Policy, 29(2), 109-123. https://doi.org/10.1016/S0048-7333(99)00055-4.

Etzkowitz, H., Webster, A., Gebhardt, C., \& Terra, B. R. C. (2000). The future of the university and the university of the future: Evolution of ivory tower to entrepreneurial paradigm. Research Policy, 29(2), 313-330. https://doi.org/10.1016/S0048-7333(99)00069-4. 
Etzkowitz, H., \& Zhou, C. (2018). Innovation incommensurability and the science park. $R$ and $D$ Management, 48, 73-87. https://doi.org/10.1111/radm.12266.

Feldman, J. M. (2007). The managerial equation and innovation platforms: The case of Linköping and Berzelius science park. European Planning Studies, 15(8), 1027-1045. https://doi.org/10.1080/09654 310701448162.

Feldman, M., Siegel, D., \& Wright, M. (2019). New developments in innovation and entrepreneurial ecosystems. Industrial and Corporate Change, 28(4), 817-826.

Felsenstein, D. (1994). University-related science parks_ “seedbeds" or "enclaves" of innovation? Technovation, 14(2), 93-110. https://doi.org/10.1016/0166-4972(94)90099-X.

Ferguson, R., \& Olofsson, C. (2004). Science parks and the development of NTBFs-Location, survival and growth. The Journal of Technology Transfer, 29(1), 5-17. https://doi.org/10.1023/b:jott.0000011178 .44095.cd.

Fernández-Alles, M., Camelo-Ordaz, C., \& Franco-Leal, N. (2014). Key resources and actors for the evolution of academic spin-offs. Journal of Technology Transfer, 40(6), 976-1002. https://doi.org/10.1007/ s10961-014-9387-2.

Fikirkoca, A., \& Saritas, O. (2012). Foresight for science parks: The case of Ankara University. Technology Analysis \& Strategic Management, 24(10), 1071-1085. https://doi.org/10.1080/09537325.2012.72368 8.

Fukugawa, N. (2006). Science parks in Japan and their value-added contributions to new technology-based firms. International Journal of Industrial Organization, 24(2), 381-400. https://doi.org/10.1016/j. ijindorg.2005.07.005.

Fuller, D., Beynon, M., \& Pickernell, D. (2019). Indexing third stream activities in UK universities: Exploring the entrepreneurial/enterprising university. Studies in Higher Education, 44(1), 86-110.

Gebauer, A., Nam, C. W., \& Parsche, R. (2005). Regional technology policy and factors shaping local innovation networks in small German cities. European Planning Studies. https://doi.org/10.1080/09654 310500139301.

Gerstlberger, W. (2004). Regional innovation systems and sustainability-Selected examples of international discussion. Technovation, 24(9), 749-758. https://doi.org/10.1016/S0166-4972(02)00152-9.

Giaretta, E. (2013). The trust "builders" in the technology transfer relationships: An Italian science park experience. Journal of Technology Transfer, 39(5), 675-687. https://doi.org/10.1007/s1096 1-013-9313-z.

Gkypali, A., Kokkinos, V., Bouras, C., \& Tsekouras, K. (2016). Science parks and regional innovation performance in fiscal austerity era: Less is more? Small Business Economics, 47(2), 313-330. https://doi. org/10.1007/s11187-016-9717-x.

Guadix, J., Carrillo-Castrillo, J., Onieva, L., \& Navascués, J. (2016). Success variables in science and technology parks. Journal of Business Research, 69(11), 4870-4875. https://doi.org/10.1016/j.jbusr es.2016.04.045.

Gunasekara, C. (2006). Reframing the role of Universities in the development of regional innovation systems. Journal of Technology Transfer, 31(1), 101-113. https://doi.org/10.1007/s10961-005-5016-4.

Guy, I. (2002). A look at aston science park. Technovation, 16(5), 217-218. https://doi.org/10.1016/01664972(96)00002-8.

Gwebu, K. L., Sohl, J., \& Wang, J. (2019). Differential performance of science park firms: An integrative model. Small Business Economics, 52(1), 193-211. https://doi.org/10.1007/s11187-018-0025-5.

Hansson, F., Husted, K., \& Vestergaard, J. (2005). Second generation science parks: From structural holes jockeys to social capital catalysts of the knowledge society. Technovation, 25(9), 1039-1049. https:// doi.org/10.1016/j.technovation.2004.03.003.

Harper, J. C., \& Georghiou, L. (2005). Foresight in innovation policy: Shared visions for a science park and business-University links in a city region. Technology Analysis \& Strategic Management, 17(2), 147-160. https://doi.org/10.1080/09537320500088716.

Helmers, C. (2019). Choose the neighbor before the house: Agglomeration externalities in a UK science park. Journal of Economic Geography, 19, 31-55. https://doi.org/10.1093/jeg/lbx042.

Hobbs, K. G., Link, A. N., \& Scott, J. T. (2017). Science and technology parks: An annotated and analytical literature review. Journal of Technology Transfer, 42(4), 957-976. https://doi.org/10.1007/s1096 1-016-9522-3.

Hommen, L., Doloreux, D., \& Larsson, E. (2006). Emergence and growth of mjardevi science park in linkoping, Sweden. European Planning Studies, 14(10), 1331-1361. https://doi.org/10.1080/09654 310600852555.

Hu, A. G. (2007). Technology parks and regional economic growth in China. Research Policy, 36(1), 76-87. https://doi.org/10.1016/j.respol.2006.08.003. 
Hu, T.-S. (2008). Interaction among high-tech talent and its impact on innovation performance: A comparison of taiwanese science parks at different stages of development. European Planning Studies, 16(2), 163-187. https://doi.org/10.1080/09654310701814462.

Hu, T.-S., Lin, C.-Y., \& Chang, S.-L. (2005). Technology-based regional development strategies and the emergence of technological communities: A case study of HSIP. Taiwan. Technovation, 25(4), 367380. https://doi.org/10.1016/j.technovation.2003.09.002.

Huang, W. J., \& Fernández-Maldonado, A. M. (2016). High-tech development and spatial planning: Comparing the Netherlands and Taiwan from an institutional perspective. European Planning Studies, 24(9), 1662-1683. https://doi.org/10.1080/09654313.2016.1187717.

Huang, K. F., Yu, C. M. J., \& Seetoo, D. H. (2012). Firm innovation in policy-driven parks and spontaneous clusters: The smaller firm the better? Journal of Technology Transfer, 37(5), 715-731. https ://doi.org/10.1007/s10961-012-9248-9.

Ishizaka, A., Pickernell, D., Huang, S., \& Senyard, J. M. (2020). Examining knowledge transfer activities in UK universities: Advocating a PROMETHEE-based approach. International Journal of Entrepreneurial Behavior \& Research, https://doi.org/10.1108/IJEBR-01-2020-0028.

Jonsson, O. (2002). Innovation Processes and Proximity: The Case of IDEON Firms in Lund, Sweden. European Planning Studies, 10(6), 705-722. https://doi.org/10.1080/0965431022000003771.

Keupp, M. M., Palmi`e, M., \& Gassmann, O. (2012). A reflective review of disruptive innovation theory. International Journal of Management Reviews, 14, 367-390.

Kihlgren, A. (2003). Promotion of innovation activity in Russia through the creation of science parks: The case of St Petersburg (1992-1998). Technovation, 23(1), 65-76. https://doi.org/10.1016/ S0166-4972(01)00077-3.

Koh, F. C., Koh, W. T., \& Tschang, F. T. (2005). An analytical framework for science parks and technology districts with an application to Singapore. Journal of business venturing, 20(2), 217-239.

Kramer, J. P., Marinelli, E., Iammarino, S., \& Diez, J. R. (2011). Intangible assets as drivers of innovation: Empirical evidence on multinational enterprises in German and UK regional systems of innovation. Technovation, 31(9), 447-458. https://doi.org/10.1016/j.technovation.2011.06.005.

Lai, H. C., \& Shyu, J. Z. (2005). A comparison of innovation capacity at science parks across the Taiwan Strait: The case of Zhangjiang High-Tech Park and Hsinchu Science-based Industrial Park. Technovation, 25(7), 805-813. https://doi.org/10.1016/j.technovation.2003.11.004.

Lamperti, F., Mavilia, R., \& Castellini, S. (2017). The role of Science Parks: A puzzle of growth, innovation and R\&D investments. Journal of Technology Transfer, 42(1), 158-183. https://doi. org/10.1007/s10961-015-9455-2.

Layson, S. K., Leyden, D. P., \& Neufeld, J. (2008). To admit or not to admit: The question of research park size. Economics of Innovation and New Technology, 17(7-8), 691-699. https://doi. org/10.1080/10438590701785652.

Lecluyse, L., Knockaert, M., \& Spithoven, A. (2019). The contribution of science parks: A literature review and future research agenda. Journal of Technology Transfer, 44(2), 559-595. https://doi. org/10.1007/s10961-018-09712-x.

Lee, W., \& Yang, W. (2000). Cradle of Taiwan high technology industry development - Hsinchu Science Park (HSP). Technovation, 20(1), 55-59.

Lenger, A. (2008). Regional innovation systems and the role of state: Institutional design and state universities in Turkey. European Planning Studies, 16(8), 1101-1120. https://doi.org/10.1080/09654 310802315781.

Lew, Y. K., Khan, Z., \& Cozzio, S. (2018). Gravitating toward the quadruple helix: International connections for the enhancement of a regional innovation system in Northeast Italy. $R$ and D Management, 48, 44-59. https://doi.org/10.1111/radm.12227.

Liberati, D., Marinucci, M., \& Tanzi, G. M. (2016). Science and technology parks in Italy: Main features and analysis of their effects on the firms hosted. Journal of Technology Transfer, 41(4), 694-729. https://doi.org/10.1007/s10961-015-9397-8.

Lindelöf, P., \& Löfsten, H. (2003). Science park location and new technology-based firms in Sweden-Implications for strategy and performance. Small Business Economics. https://doi. org/10.1023/A:1022861823493.

Lindelöf, P., \& Löfsten, H. (2004). Proximity as a resource base for competitive advantage: Universityindustry links for technology transfer. The Journal of Technology Transfer, 29(3/4), 311-326. https ://doi.org/10.1023/b:jott.0000034125.29979.ae.

Lindelöf, P., \& Löfsten, H. (2006). Environmental hostility and firm behavior-An empirical examination of new technology-based firms on science parks. Journal of Small Business Management, 44(3), 386-406. https://doi.org/10.1111/j.1540-627X.2006.00178.x. 
Link, A., \& Link, K. R. (2003). On the growth of US science parks. The Journal of Technology Transfer, 28(1), 81-85. https://doi.org/10.1023/A:1021634904546.

Link, A. N., \& Scott, J. T. (2003a). The growth of research triangle park. Small Business Economics, 20(2), 167-175. https://doi.org/10.1023/A:1022216116063.

Link, A. N., \& Scott, J. T. (2003b). US science parks: The diffusion of an innovation and its effects on the academic missions of universities. International Journal of Industrial Organization, 21(9), 1323-1356. https://doi.org/10.1016/S0167-7187(03)00085-7.

Link, A., \& Scott, J. (2015). Research, Science, and Technology Parks: Vehicles for Technology Transfer, in The Chicago Handbook of University Technology Transfer and Academic Entrepreneurship (Eds: Link, Siegel, and Wright), The University of Chicago Press.

Link, A. N., \& Scott, J. T. (2017). U.S. university research parks. In Universities and the Entrepreneurial Ecosystem (pp. 44-55). https://doi.org/10.1007/s11123-006-7126-X.

Löfsten, H., \& Lindelöf, P. (2001). Science parks in Sweden-Industrial renewal and development ? R\&D Management, 31(3), 309-322. https://doi.org/10.1111/1467-9310.00219.

Löfsten, H., \& Lindelöf, P. (2002). Science Parks and the growth of new technology-based firmsAcademic-industry links, innovation and markets. Research Policy, 31(6), 859-876. https://doi. org/10.1016/S0048-7333(01)00153-6.

Löfsten, H., \& Lindelöf, P. (2003). Determinants for an entrepreneurial milieu: Science Parks and business policy in growing firms. Technovation, 23(1), 51-64. https://doi.org/10.1016/S0166 -4972(01)00086-4.

Löfsten, H., \& Lindelöf, P. (2005). R\&D networks and product innovation patterns-Academic and nonacademic new technology-based firms on Science Parks. Technovation, 25(9), 1025-1037. https:// doi.org/10.1016/j.technovation.2004.02.007.

Looy, B. Van, Debackere, K., \& Andries, P. (2003). Policies to stimulate regional innovation capabilities via university-industry collaboration: An analysis and an assessment. $R$ and D Management, 33(2), 209-229. https://doi.org/10.1111/1467-9310.00293.

Macdonald, S. (2016). Milking the myth: innovation funding in theory and practice. R\&D Management, $46(2), 552-563$.

Macpherson, A., \& Holt, R. (2007). Knowledge, learning and small firm growth: A systematic review of the evidence. Research Policy, 36(2), 172-192. https://doi.org/10.1016/j.respol.2006.10.001.

Malairaja, C., \& Zawdie, G. (2008). Science parks and university-industry collaboration in Malaysia. Technology Analysis \& Strategic Management, 20(6), 727-739. https://doi.org/10.1080/09537 320802426432.

Markman, G. D., Phan, P. H., Balkin, D. B., \& Gianiodis, P. T. (2005). Entrepreneurship and university-based technology transfer. Journal of Business Venturing, 20(2), 241-263. https://doi. org/10.1016/j.jbusvent.2003.12.003.

Markman, G. D., Siegel, D. S., \& Wright, M. (2008). Research and technology commercialization. Journal of Management Studies, 45(8), 1401-1423. https://doi.org/10.1111/j.1467-6486.2008.00803.x.

Massey, D., \& Wield, D. (2006). Science parks: A concept in science, society, and 'space' (A Realist Tale). Environment and Planning D: Society and Space, 10(4), 411-422. https://doi.org/10.1068/ d100411.

McAdam, M., \& McAdam, R. (2008). High tech start-ups in University Science Park incubators: The relationship between the start-up's lifecycle progression and use of the incubator's resources. Technovation, 28(5), 277-290. https://doi.org/10.1016/j.technovation.2007.07.012.

Mian, S., Lamine, W., \& Fayolle, A. (2016). Technology business incubation: An overview of the state of knowledge. Technovation, 50-51, 1-12. https://doi.org/10.1016/j.technovation.2016.02.005.

Mora-Valentín, E. M., Ortiz-de-Urbina-Criado, M., \& Nájera-Sánchez, J. J. (2018). Mapping the conceptual structure of science and technology parks. Journal of Technology Transfer, 43(5), 1410-1435. https://doi.org/10.1007/s10961-018-9654-8.

Motohashi, K. (2013). The role of the science park in innovation performance of start-up firms: an empirical analysis of Tsinghua Science Park in Beijing. Asia Pacific Business Review, 19(4), 578599. https://doi.org/10.1080/13602381.2012.673841.

Ng, W. K. B., Appel-Meulenbroek, R., Cloodt, M., \& Arentze, T. (2019). Towards a segmentation of science parks: A typology study on science parks in Europe. Research Policy, 48(3), 719-732. https ://doi.org/10.1016/j.respol.2018.11.004.

Pálmai, Z. (2004). An innovation park in Hungary: INNOTECH of the Budapest University of Technology and Economics. Technovation, 24(5), 421-432. https://doi.org/10.1016/S0166-4972(02)00098 -6 .

Park, S. C. (2004). The city of brain in South Korea: Daedeok science town. International Journal of Technology Management, 28(3-6), 602-614. 
Phan, P. H., Siegel, D. S., \& Wright, M. (2005). Science parks and incubators: Observations, synthesis and future research. Journal of Business Venturing, 20(2), 165-182. https://doi.org/10.1016/j. jbusvent.2003.12.001.

Phillimore, J. (1999). Beyond the linear view of innovation in science park evaluation An analysis of Western Australian Technology Park. Technovation, 19(11), 673-680.

Pickernell, D., Ishizaka, A., Huang, S., \& Senyard, J. (2019). Entrepreneurial university strategies in the UK context: Towards a research agenda. Management Decision.

Pilar Latorre, M., Hermoso, R., \& Rubio, M. A. (2017). A novel network-based analysis to measure efficiency in science and technology parks: The ISA framework approach. Journal of Technology Transfer, 42(6), 1255-1275. https://doi.org/10.1007/s10961-017-9585-9.

Pittaway, L., Robertson, M., Munir, K., Denyer, D., \& Neely, A. (2004). Networking and innovation: A systematic review of the evidence. International Journal of Management Reviews, 5(3-4), 137-168.

Quintas, P., Wield, D., \& Massey, D. (1992). Academic-industry links and innovation: Questioning the science park model. Technovation, 12(3), 161-175. https://doi.org/10.1016/0166-4972(92)90033-E.

Radosevic, S., \& Myrzakhmet, M. (2009). Between vision and reality: Promoting innovation through technoparks in an emerging economy. Technovation, 29(10), 645-656. https://doi.org/10.1016/j. technovation.2009.04.001.

Ramasamy, B., Chakrabarty, A., \& Cheah, M. (2004). Malaysia's leap into the future: An evaluation of the multimedia super corridor. Technovation, 24(11), 871-883. https://doi.org/10.1016/S0166 -4972(03)00049-X.

Ramirez, M., Li, X., \& Chen, W. (2013). Comparing the impact of intra-and inter-regional labour mobility on problem-solving in a Chinese science park. Regional Studies, 47(10), 1734-1751.

Ramírez-Alesón, M., \& Fernández-Olmos, M. (2018). Unravelling the effects of Science Parks on the innovation performance of NTBFs. Journal of Technology Transfer, 43(2), 482-505. https://doi. org/10.1007/s10961-017-9559-y.

Ratinho, T., \& Henriques, E. (2010). The role of science parks and business incubators in converging countries: Evidence from Portugal. Technovation, 30(4), 278-290. https://doi.org/10.1016/j.techn ovation.2009.09.002.

Rip, A. (2002). Regional innovation systems and the advent of strategic science. Journal of Technology Transfer, 27(1), 123-131. https://doi.org/10.1023/A:1013108906611.

Salvador, E. (2011). Are science parks and incubators good "brand names" for spin-offs? The case study of Turin. Journal of Technology Transfer, 36(2), 203-232. https://doi.org/10.1007/s1096 1-010-9152-0.

Savino, T., Messeni Petruzzelli, A., \& Albino, V. (2017). Search and recombination process to innovate: A review of the empirical evidence and a research agenda. International Journal of Management Reviews, 19(1), 54-75.

Shearmur, R., \& Doloreux, D. (2000). Science parks: Actors or reactors? Canadian science parks in their urban context. Environment and Planning A, 32(6), 1065-1082. https://doi.org/10.1068/a32126.

Siegel, D. S., Westhead, P., \& Wright, M. (2003a). Assessing the impact of university science parks on research productivity: Exploratory firm-level evidence from the United Kingdom. International Journal of Industrial Organization, 21(9), 1357-1369. https://doi.org/10.1016/S0167-7187(03)00086-9.

Siegel, D. S., Westhead, P., \& Wright, M. (2003b). Science parks and the performance of new technology-based firms: A review of recent UK Evidence and an Agenda for future research. Small Business Economics. https://doi.org/10.1023/A:1022268100133.

Sofouli, E., \& Vonortas, N. S. (2007). S\&T Parks and business incubators in middle-sized countries: The case of Greece. Journal of Technology Transfer, 32(5), 525-544. https://doi.org/10.1007/s1096 1-005-6031-1.

Squicciarini, M. (2008). Science Parks' tenants versus out-of-Park firms: Who innovates more? A duration model. Journal of Technology Transfer, 33(1), 45-71. https://doi.org/10.1007/s10961-007-9037-z.

Staudt, E., Bock, J., \& Muhlemeyer, P. (1994). Technology centres and science parks: Agents or competence centres for small businesses? International Journal of Technology Management, 9(2), 213-226.

Storey, D. J., \& Tether, B. S. (1998). Public policy measures to support new technology-based firms in the European Union. Research Policy, 26(9), 1037-1057. https://doi.org/10.1016/S0048 -7333(97)00058-9.

Takeda, Y., Kajikawa, Y., Sakata, I., \& Matsushima, K. (2008). An analysis of geographical agglomeration and modularized industrial networks in a regional cluster: A case study at Yamagata prefecture in Japan. Technovation, 28(8), 531-539. https://doi.org/10.1016/j.technovation.2007.12.006.

Tan, J. (2006). Growth of industry clusters and innovation: Lessons from Beijing Zhongguancun Science Park. Journal of Business Venturing, 21(6), 827-850. https://doi.org/10.1016/j.jbusvent.2005.06.006. 
Tödtling, F., \& Kaufmann, A. (2002). SMEs in regional innovation systems and the role of innovation support-The case of upper Austria. Journal of Technology Transfer, 27(1), 15-26. https://doi. org/10.1023/A:1013140318907.

Tranfield, D., Denyer, D., \& Smart, P. (2003). Towards a methodology for developing evidence-informed management knowledge by means of systematic review*introduction: the need for an evidenceinformed approach. British Journal of Management, 14(3), 207-222.

Tsai, M. C., Wen, C. H., \& Chen, C. S. (2007). Demand choices of high-tech industry for logistics service providers-an empirical case of an offshore science park in Taiwan. Industrial Marketing Management, 36(5), 617-626. https://doi.org/10.1016/j.indmarman.2006.03.002.

Turner, N., Swart, J., \& Maylor, H. (2013). Mechanisms for managing ambidexterity: A review and research agenda. International Journal of Management Reviews, 15(3), 317-332.

Ubeda, F., Ortiz-de-Urbina-Criado, M., \& Mora-Valentín, E. M. (2019). Do firms located in science and technology parks enhance innovation performance? The effect of absorptive capacity. Journal of Technology Transfer, 44(1), 21-48. https://doi.org/10.1007/s10961-018-9686-0.

Vaidyanathan, G. (2008). Technology parks in a developing country: The case of India. The Journal of Technology Transfer, 33(3), 285-299.

Vásquez-Urriago, Á. R., Barge-Gil, A., \& Modrego Rico, A. (2016). Science and Technology Parks and cooperation for innovation: Empirical evidence from Spain. Research Policy, 45(1), 137-147. https://doi.org/10.1016/j.respol.2015.07.006.

Vedovello, C. (2002). Science parks and university-industry interaction: Geographical proximity between the agents as a driving force. Technovation, 17(9), 491-531. https://doi.org/10.1016/ s0166-4972(97)00027-8.

Watkins-Mathys, L., \& Foster, M. J. (2006). Entrepreneurship: The missing ingredient in China's STIPs? Entrepreneurship and Regional Development, 18(3), 249-274. https://doi.org/10.1080/08985 620600593161.

Westhead, P. (1997). R\&D "inputs" and "outputs" of technology-based firms located on and off Science Parks. $R$ and D Management, 27(1), 45-62. https://doi.org/10.1111/1467-9310.00041.

Westhead, P., \& Batstone, S. (1998). Independent technology-based firms: The perceived benefits of a science park location. Urban Studies, 35(12), 2197-2219. https://doi.org/10.1080/0042098983845.

Williams, M. (2002). Generalizations in qualitative research. In T. May (Ed.), Qualitative research in action (pp. 125-143). London: Sage.

Wonglimpiyarat, J. (2010). Commercialization strategies of technology: Lessons from Silicon Valley. The Journal of Technology Transfer, 35(2), 225-236.

Wright, M, Link, A. N., \& Amoroso, S. (2019). Lessons learned and a future and policy agenda on science parks in science and technology parks and regional economic development, (Eds: Amoroso, Link, Wright), Palgrave Advances in the Economics of Innovation and Technology. https://doi. org/10.1007/978-3-030-30963-3_12.

Wright, M., Liu, X., Buck, T., \& Filatotchev, I. (2008). Returnee entrepreneurs, science park location choice and performance: An analysis of high-technology SMEs in China. Entrepreneurship: Theory and Practice, 32(1), 131-155. https://doi.org/10.1111/j.1540-6520.2007.00219.x.

Wright, M., Siegel, D., \& Mustar, P. (2017). An emerging ecosystem for student start-ups. Journal of Technology Transfer, 42(4), 909-922.

Xie, K., Song, Y., Zhang, W., Hao, J., Liu, Z., \& Chen, Y. (2018). Technological entrepreneurship in science parks: A case study of Wuhan Donghu High-Tech Zone. Technological Forecasting and Social Change, 135, 156-168. https://doi.org/10.1016/j.techfore.2018.01.021.

Yang, D. Y. R., Hsu, J. Y., \& Ching, C. H. (2009a). Revisiting the silicon Island? The geographically varied "Strategic Coupling" in the development of high-technology parks in Taiwan. Regional Studies, 43(3), 369-384. https://doi.org/10.1080/00343400902777067.

Yang, C. H., Motohashi, K., \& Chen, J. R. (2009b). Are new technology-based firms located on science parks really more innovative? Evidence from Taiwan. Research Policy, 38(1), 77-85. https://doi. org/10.1016/j.respol.2008.09.001.

Yoon, H., Yun, S., Lee, J., \& Phillips, F. (2015). Entrepreneurship in East Asian regional innovation systems: Role of social capital. Technological Forecasting and Social Change, 100, 83-95. https://doi. org/10.1016/j.techfore.2015.06.028.

Zhang, F. (2015). Building biotech in Shanghai: A perspective of regional innovation system. European Planning Studies, 23(10), 2062-2078. https://doi.org/10.1080/09654313.2014.1001322.

Zhu, D., \& Tann, J. (2005). A regional innovation system in a small-sized region: A clustering model in Zhongguancun Science Park. Technology Analysis \& Strategic Management, 17(3), 375-390. https:// doi.org/10.1080/09537320500211789. 
Zou, Y., \& Zhao, W. (2013). Anatomy of Tsinghua University science park in China: Institutional evolution and assessment. Journal of Technology Transfer, 39(5), 663-674. https://doi.org/10.1007/s1096 1-013-9314-y.

Publisher's Note Springer Nature remains neutral with regard to jurisdictional claims in published maps and institutional affiliations. 